\title{
Biodegradable polymer films from seaweed polysaccharides: A review on cellulose as a reinforcement material
}

\author{
H. P. S. Abdul Khalil ${ }^{*}$, Y. Y. Tye ${ }^{1}$, C. K. Saurabh ${ }^{1}$, C. P. Leh ${ }^{1}$, T. K. Lai ${ }^{1}$, E. W. N. Chong ${ }^{1}$, \\ M. R. Nurul Fazita ${ }^{1}$, J. Mohd Hafiidz ${ }^{1}$, A. Banerjee ${ }^{2}$, M. I. Syakir ${ }^{1}$ \\ ${ }^{1}$ School of Industrial Technology, Universiti Sains Malaysia, 11800 Penang, Malaysia \\ ${ }^{2}$ Department of Biotechnology \& Microbiology, Tilak College of Science \& Commerce, University of Mumbai, \\ 400032 Mumbai, India
}

Received 5 September 2016; accepted in revised form 10 November 2016

\begin{abstract}
Seaweed and cellulose are promising natural polymers. This article reviews the basic information and recent developments of both seaweed and cellulose biopolymer materials as well as analyses the feasible formation of seaweed/cellulose composite films. Seaweed and cellulose both exhibit interesting film-forming properties. Nevertheless, seaweed has poor water vapour barrier and mechanical properties, whereas cellulose is neither meltable nor soluble in water or common organic solvents due to its highly crystalline structure. Therefore, modification of these hydrocolloids has been done to exploit their useful properties. Blending of biopolymers is a must recommended approach to improve the desired characteristics. From the review, seaweed is well compatible with cellulose, which possesses excellent mechanical strength and water resistance properties. Moreover, seaweed/cellulose composite films can prolong a product's shelf life while maintaining its biodegradability. Additionally, the films show potential in contributing to the bioeconomy. In order to widen seaweed and cellulose in biocomposite application across various industries, some of the viewpoints are highlighted to be focused for future developments and applications.
\end{abstract}

Keywords: biodegradable polymers, reinforcement, composite film, cellulose, seaweed

\section{Introduction}

Edible and degradable polymers are a type of material made from renewable and edible ingredients such as, polysaccharides, proteins and lipids, which degrade more readily than non-renewable petroleum-based polymers. This polymer has been used in food and biomaterial products or as packaging films in food coatings or wrappings due to its degradable properties and preservative capabilities, which are of great benefit to the environment and health [1]. Polysaccharide is promising edible polymer as, it is cheap, readily available, biocompatible and environmentally friendly $[2,3]$. Cellulose, starch and chitosan are natural renewable sources of polysaccharide, which has been commonly applied as an edible film in agricultural products for the purpose of prolonging the shelf life of fresh fruits and vegetables, reducing the oil/fat absorption in fried food and hindering the loss of food flavour [3, 4].

Recently, seaweed has received much interest and attention in applications related to energy, food, tissue engineering, and biosensors, as well as drug delivery applications [5]. Similar to other polysaccharide materials, seaweed is also a green, abundantly available and inexpensive source of polysaccharide; the only difference is it is harvested from the sea [6]. Alginate, carrageenan and agar are common seaweed-derived products that exhibit interesting filmforming properties [7-9]. However, seaweed films exhibit relatively low water vapour barrier properties

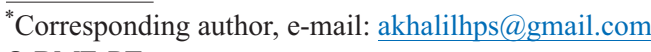
(C) BME-PT 
and mechanical strength compare to conventional non-renewable polymers. Therefore, seaweed is usually mixed with other components to improve the properties of seaweed films.

Cellulose is a commercially important polysaccharide. Since cellulose is capable of forming hydrocolloids in a suitable solvent system, it is an excellent film-making material. Cellulose film has been reported to have higher water and microwave heating resistances [10]. Moreover, cellulose has attracted significant interest as a reinforcement material in polymer matrix composites. In addition, it also blends with other hydrocolloids, which widens its applications. Past researches have shown that the addition of cellulose and/or its derivatives into a polymeric matrix can increase the tensile strength and rigidity of the film $[9,10]$.

Generally, edible films made from only one type of natural film-forming polymer possess a mix of good and bad properties. Therefore, the alternative approach of blending the biopolymers into biocomposite materials is applied to improve the properties of edible films [11]. Since seaweed blends with cellulose are a new research area, a literature review that covers the published reports of edible composite films made of seaweed and cellulose is necessary. Hence, this paper reviews the fundamental knowledge and current state of research into seaweed and cellulose as edible polymeric materials. Furthermore, this review also analyses the compatibility of seaweed and cellulose based on the structure and properties of the composite film, as well as the environmental (biodegradable) and economic aspects of this composite film. Future development of seaweed/cellulose composite film is discussed as well.

\section{Seaweed derivatives}

Seaweeds (or marine macro-algae) are plant-like organisms that generally live attached to rock or other hard substrata in coastal areas. They are abundantly available, able to grow in wide range of environments, cost effective and easy to cultivate in natural environment as well as harvest year around. In general, they are classified as red (Rhodophyta), brown (Phaeophyta), and green (Chlorophyta) seaweeds. Red and brown seaweeds are almost exclusively found in the ocean, whilst green alga is common in freshwater such as rivers and lakes, and even in terrestrial situations. Seaweeds have a high concentration of vitamins and minerals, which represents an obvious
Table 1. Chemical composition of seaweeds [14]

\begin{tabular}{|l|l|}
\hline \multicolumn{1}{|c|}{ Components } & \multicolumn{1}{c|}{ Compositions } \\
\hline Water & $80-90 \%$ \\
\hline Carbohydrates & $50 \%$ dry weight \\
\hline Proteins & $\begin{array}{l}\text { Brown seaweed: } 3-15 \% \text { dry weight } \\
\text { Red or Green seaweeds: } 10-47 \% \text { dry weight }\end{array}$ \\
\hline Minerals & $7-38 \%$ dry weight \\
\hline Lipids & $1-3 \%$ dry weight \\
\hline
\end{tabular}

health benefit. Therefore, seaweeds (mostly red and brown seaweeds) are typically used as herbal medicine and a human food source. Since they are edible and rich in beneficial nutrients, they can be eaten in raw salads, soups, cookies, meals, and condiments. Although the chemical composition of all seaweed species is similar, the percentage of protein content is different according to the species (Table 1) [12,13]. According to Table 1, brown seaweed contains approximately $3-15 \%$ protein, whereas red and green seaweeds contain $10-47 \%$ protein (Table 1).

In addition to the importance of seaweed as a food in its original form, its excellent carbohydrate content has promoted the industrial use of seaweed species as a source of hydrocolloids (seaweed derivatives), such as alginate, carrageen and agar, in the fields of food technology, biotechnology, microbiology, and medicine as well as in the plastics industry (Table 2) [7, 12]. These hydrocolloids are defined as longchain hydrophilic polymers (polysaccharides) that are characterized by their ability to form viscous dispersions and/or gels when dispersed in water. Hence, they are commonly utilized as thickening or gelling agents to control the functional properties of aqueous solutions.

Table 2. Polysaccharides that available in red, brown and green seaweeds $[12,15]$

\begin{tabular}{|l|c|c|c|}
\hline \multicolumn{1}{|c|}{ Polysaccharides } & $\begin{array}{c}\text { Red } \\
\text { seaweed }\end{array}$ & $\begin{array}{c}\text { Brown } \\
\text { seaweed }\end{array}$ & $\begin{array}{c}\text { Green } \\
\text { seaweed }\end{array}$ \\
\hline Agar & $\sqrt{ }$ & - & - \\
\hline Alginate & - & $\sqrt{ }$ & - \\
\hline Carrageenan & $\sqrt{ }$ & - & - \\
\hline Cellulose & $\sqrt{ }$ & $\sqrt{ }$ & $\sqrt{ }$ \\
\hline FlorideanStarch( $\alpha-1,4-$ bindingglucan $)$ & $\sqrt{ }$ & - & - \\
\hline Fucoidan(sulphatedfucose) & - & $\sqrt{ }$ & - \\
\hline Laminarin( $\beta-1,3$ glucan) & - & $\sqrt{ }$ & - \\
\hline Mannan & $\sqrt{ }$ & - & - \\
\hline Mannitol & - & $\sqrt{ }$ & - \\
\hline Porphyran & $\sqrt{ }$ & - & - \\
\hline Sargassan & - & $\sqrt{ }$ & - \\
\hline Sulphatedgalactans & $\sqrt{ }$ & - & $\sqrt{ }$ \\
\hline Sulphuric acid polysaccharides & - & - & $\sqrt{ }$ \\
\hline Xylans & $\sqrt{ }$ & - & $\sqrt{ }$ \\
\hline
\end{tabular}




\subsection{Alginate}

Alginate is the most abundant polysaccharide in brown seaweed, making up as much as $40 \%$ of the dry weight [16]. Alginate is a hydrophilic colloidal carbohydrate extracted from brown seaweed using dilute alkaline solution. It is composed of a monomeric unit of $(1 \rightarrow 4)$-linked $\beta$-D-mannuronic acid (M) and $\alpha$-L-guluronic acid $(\mathrm{G})$ residues (Figure 1 ) and is commonly used as thickening, stabilizing, suspending, film-forming, gel-producing, and emulsion-stabilizing agents [19]. As a gelling agent, alginate solutions can rapidly form gels in the presence of various divalent metal cations, such as calcium, magnesium, manganese, aluminium, and iron. Therefore, alginate shows interesting gel-forming properties. Among the divalent ions, calcium ions are commonly reacted with alginate to form a strong gel or low solubility polymer. These ions aid in the association of $M$ and $G$ blocks. In general, the length of the $G$ blocks determines the alginate's ability and selectivity in forming these interactions, whereas $\mathrm{M}$ and MG blocks are almost without selectivity. The diffusion of ions into the alginate solution triggers an anion exchange process, in which the water-soluble alginate exchanges its counter ions with $\mathrm{Ca}^{2+}$, producing a gel transition. This ionic crosslinking rapidly forms a cold-setting and heat-stable gel. When forming alginate gels, two adjacent, diaxially linked guluronic residues $(\mathrm{G})$ form a cavity that acts as a binding site for calcium ions (Figure 2). As a result, the gel characteristics and properties can be improved $[18,20$,
21]. Nevertheless, the alginate gel may dissociate in the presence of acids, although it can be stable from $0-100^{\circ} \mathrm{C}[2]$.

\subsection{Carrageenan}

Carrageenan is a water soluble polymer with a linear chain of partially sulfonated galactans. These sulfonated polysaccharides are extracted from red seaweed using dilute alkaline solution. After extraction, the dilute extracts ( $1-2 \%$ carrageenan) are filtered, concentrated, and then precipitated with isopropanol to give a fibrous coagulum. Subsequently, the coagulum is pressed to remove solvent and washed. Lastly, it is then dried and milled to an appropriate particle size [18]. Since carrageenan can form a gel through ionotropic gelation coupled to a mechanism that involves helix formation upon cooling and crosslinking in the presence of potassium or calcium ions, it has great potential as a gel-forming material (Figure 3). In general, carrageenan is used as a gel to increase the viscosity of foods such as ice cream, sauces, and sweetened condensed milk [1,22]. There are three types of carrageenan that exhibit different chemical structures (Figure 1) and gelation properties: kappa-carrageenan forms rigid and brittle gels; iota-carrageenan produces softer, elastic and cohesive gels; and lambda-carrageenan does not form gels. These differences can be attributed to their difference in sulphate groups and anhydro bridges, and these materials can be used to form polymer particles by different production methods $[2,23]$.

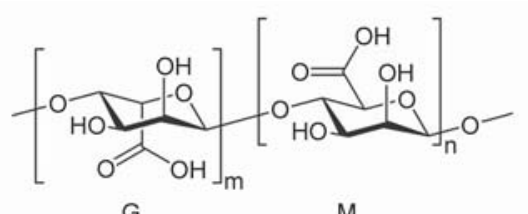

a)

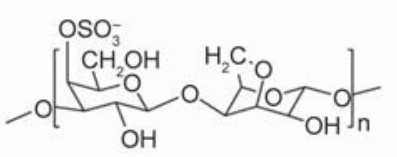

b)

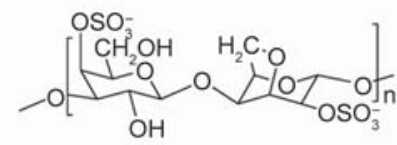

lota-carrageenan

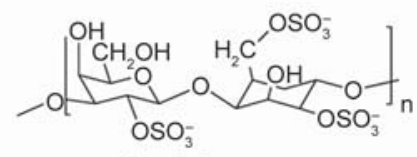

Lambda-carrageenan

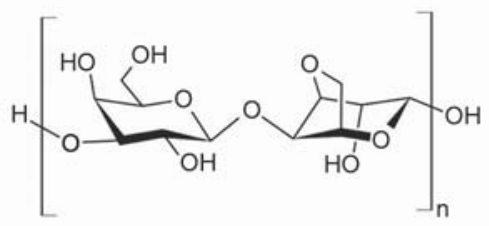

Figure 1. Chemical structures of the seaweed derived hydrocolloids (a) alginates, (b) carrageenans and (c) agars [17, 18] 

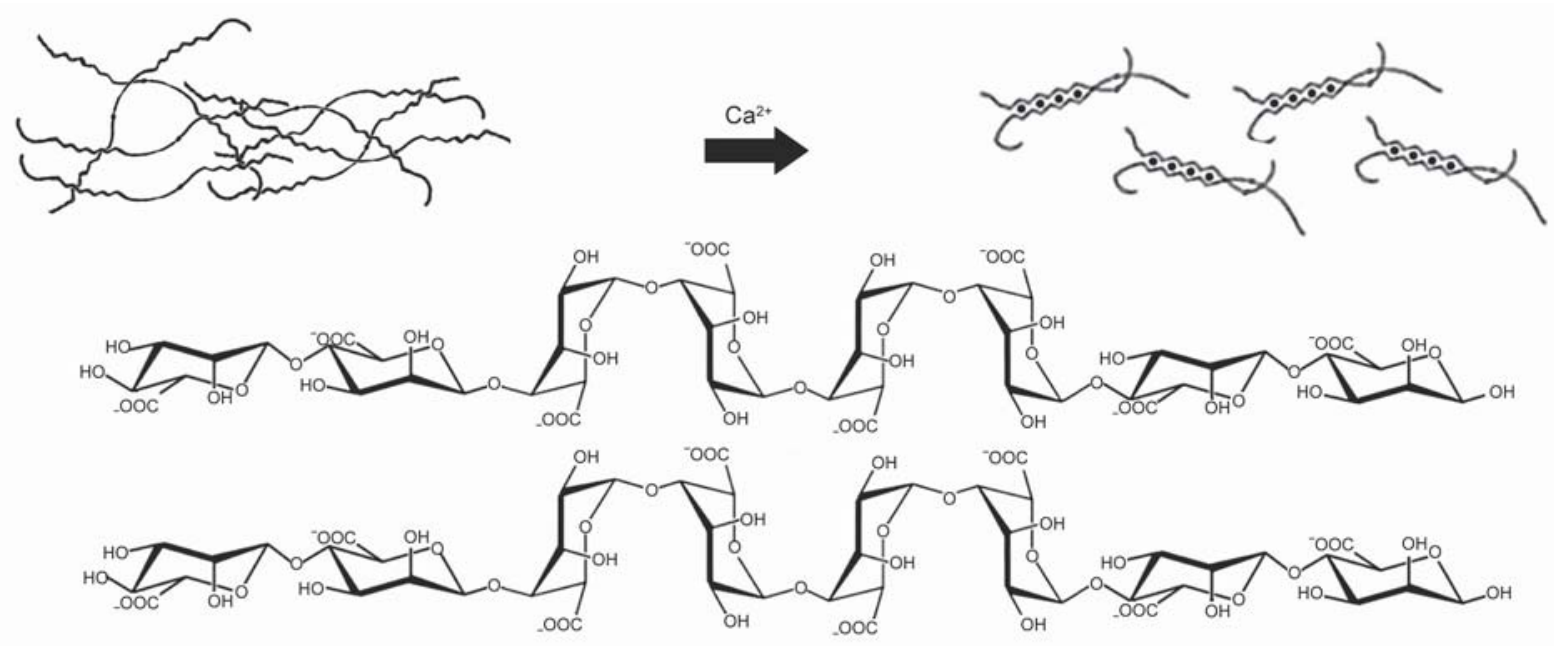

M

M

G

$\underbrace{\mathrm{Ca}^{2 *}}$

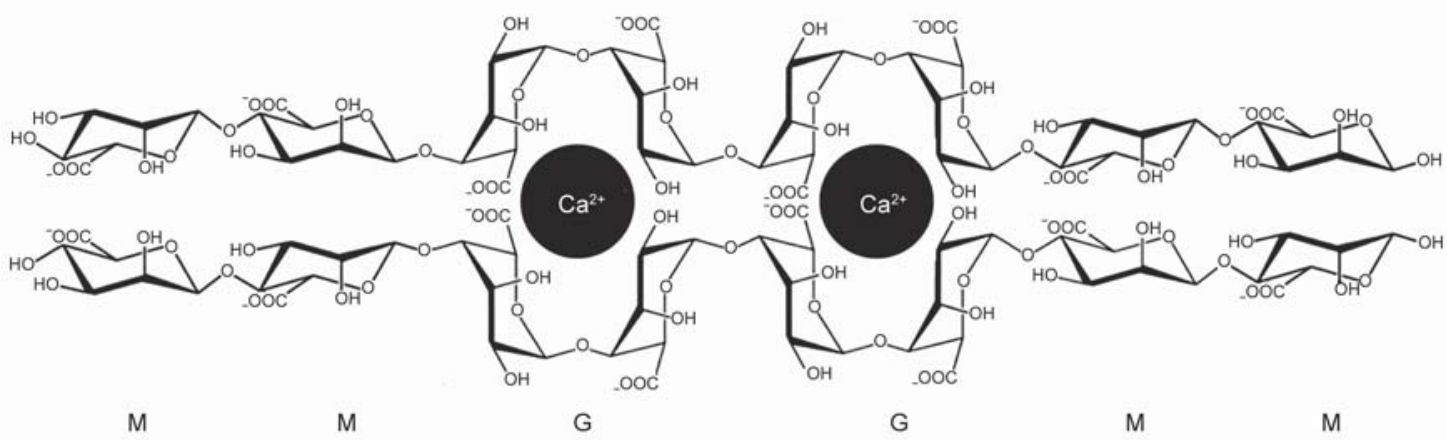

Figure 2. Gelling mechanism of calcium cross-linked alginate (egg-box like conformation) [18]
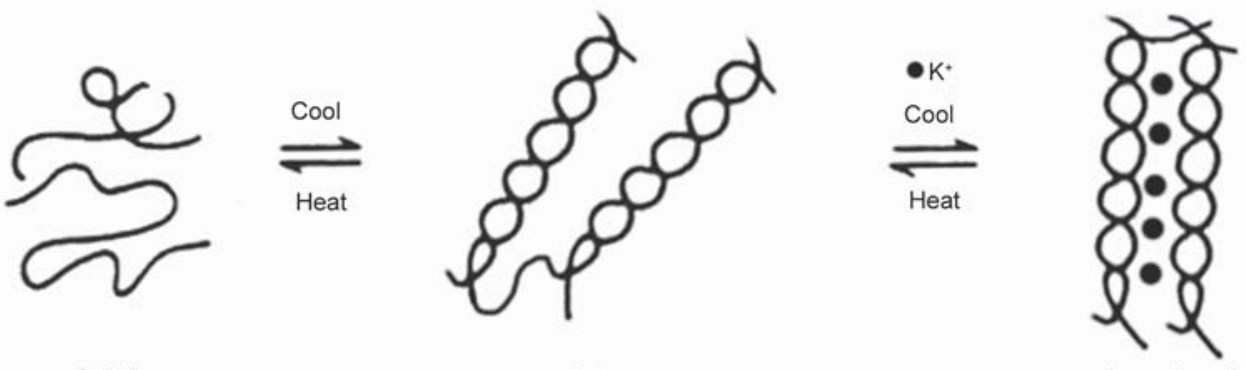

a)

Solution

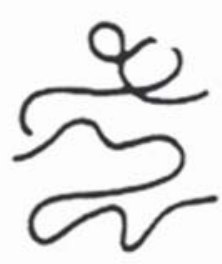

b)

Solution
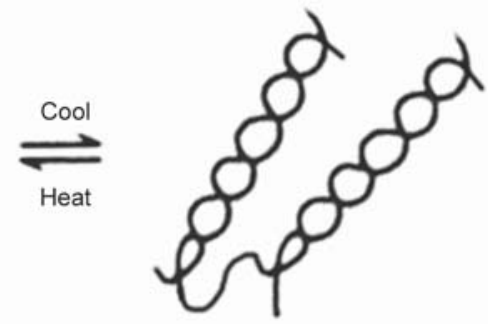

Gel

(helix formation)

Ageing

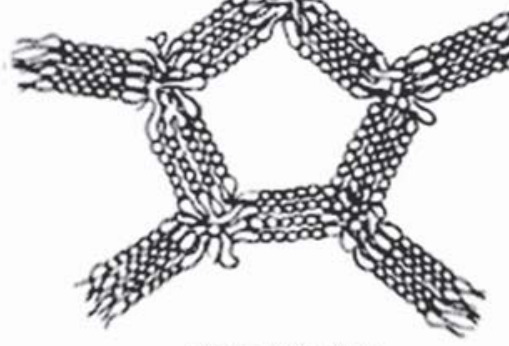

Final gel structure

Figure 3. Gelling mechanism for (a) carrageenans and (b) agars [17, 18] 


\subsection{Agar}

Agar has been widely used as a gelling agent in the food industry due to its hydrophilic colloidal properties, arising from a mixture of agarose and agaropectin, and its ability to form reversible gels simply by cooling the hot aqueous solution (Figure 1 and Figure 3). Moreover, it is also commonly used as microbiological media to provide firmness. The resulting gels are clear, transparent, relatively brittle, and melt upon heating. Nevertheless, despite its degradability and its excellent gelling power, agar has not been used extensively due to its poor ageing properties. Both photodegradation and fluctuations in ambient temperature and humidity can alter the agar's crystallinity, thus leading to the formation of microfractures and polymer embrittlement $[1,2,22]$.

\section{Cellulose and its derivatives}

Cellulose is the most abundantly available carbohydrate in the world. It has been extensively used in many modern industries due to its inexpensive, degradable, renewable and interesting properties. The existence of cellulose as the common material in plant cell walls was first recognized by Anselm Payen in 1838 [25]. Cellulose is a polysaccharide chain that consists of D-glucopyranose units joined by $\beta-1,4$-glycoside linkages. The link in the cellulose chain consists of a simple sugar, $\beta$-D-glucose. Although cellulose, in general, is considered to be a plant material, some bacteria have also been found to produce cellulose, which is known as bacterial cellulose. Figure 4 shows the types of cellulose and theirs applications [24-27].

\subsection{Plant cellulose}

Cellulose fibre from plants can be obtained from wood (softwood and hardwood) and non-wood (agricultural waste, native plants and non-wood plant fibre) lignocellulosic biomasses. Most lignocellulosic biomasses are comprised of approximately 40 $60 \%$ cellulose, $20-30 \%$ hemicellulose and $10-25 \%$ lignin. Thus, cellulose is the main constituent in plant fibre, and it exhibits a wide range of crystallinity (20-90\%). Generally, cellulose is bound together by an amorphous lignin matrix, which protects against biological attack, gravitational forces and wind. Moreover, hemicellulose found in natural plant fibres is a compatibilizer for cellulose and lignin [25, 28-30]. In general, the plant fibre can be pulped to produce paper and board products, or it can be treated by sev-

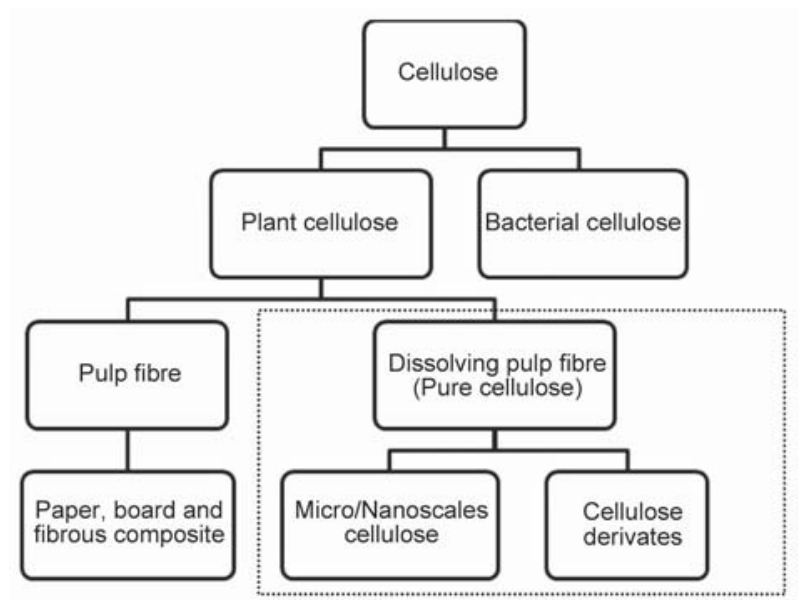

Figure 4. Categories of cellulose and their applications

eral processes such as prehydrolysis or pulping to obtain pure cellulose ( $>90 \%$ cellulose content). This material can be further chemically and/or mechanically processed into modified forms such as micro/ nanoscale cellulose and cellulose derivatives (ether and ester) for use in cellulose-based composites, thin polymer films and hydrogels (Figure 4) [31].

\subsubsection{Micro/Nanoscale cellulose}

Cellulose from plant fibre is the most abundant renewable polymer resource available today, and it is considered to be an almost infinite source of raw material which can fulfill the increasing demand of environmentally friendly and biocompatible products. It is sourced from wood and non-wood fibres for use as an energy source and had been used in building materials, paper, textiles and clothing. Today, one cellulose application is in composite materials to reinforce engineering polymer systems due to the excellent mechanical properties of cellulose [32]. Generally, pure cellulose is available in different forms with various mechanical properties. The difference between the various forms of cellulose is related to the shape, size and degree of crystallinity of their particles [33].

The plant cell wall mainly consists of three layers: primary, secondary and middle layers. The primary cell wall is the thin first layer deposited during cell growth, and it encircles the secondary wall. The secondary cell wall is composed of three layers, and the thick middle layer determines the mechanical properties of the fibre. The thick middle layer consists of a series of helically wound cellular microfibrils formed from long-chain cellulose molecules [25]. In nature, cellulose microfibrils consist of alternating crystalline and non-crystalline domains. Therefore, 
nanoparticles can be extracted from this naturally occurring polymer.

Since interest has recently increased in materials consisting of a larger number of cellulose nanofibres or fibrils that remain attached by at least a portion of their length, several methods have been proposed to prepare and isolate these fibril materials. In general, mechanical disintegration of the pulp fibre using homogenizer equipment can release more or less of these individual microfibrils. This material is called microfibrillated cellulose (MFC), nanofibrillated cellulose (NFC) or nanocellulose [25, 34, 35]. Nevertheless, the mechanical fibrillation process consumes a large amount of energy. Therefore, chemical or enzymatic pretreatments have been suggested to reduce the energy consumption from the mechanical disintegration of pulp fibre [36]. MFC has been proposed for use as a rheology modifier due to its long and entangled fibrils, as material for functional aerogels, and as a matrix material and reinforcement component in various products [37]. In principal, a single cellulose microfibril has a diameter (or width) of approximately $2-10 \mathrm{~nm}$ with a length in the several tens of microns. Some of the cellulose microfibrils are not completely separated (formation of aggregates), and the diameter of these cellulose aggregate microfibrils are typically in the range of 10-40 $\mathrm{nm}$ (Table 3) [36].

In addition, longitudinal cutting of these cellulose microfibrils in plant cell walls can be performed by submitting the biomass to strong acid hydrolysis treatment, which allows the dissolution of the non-crystalline fraction of the microfibrils. The resulting material is denoted microcrystalline cellulose (MCC). MCC is crystalline cellulose and is much stronger and stiffer than amorphous cellulose and cellulose itself. Thus, it has been widely utilized in food, cosmetic and medical industries as a water retainer, a suspension stabilizer, and a flow characteristic con- troller in the systems used in the final products [25, 29, 34, 42]. In addition, sonication of MCC can further disentangle the fibrils. These generated particles are often referred to as nanocrystalline cellulose (NCC), cellulose whiskers or cellulose nanowhiskers, which are rod-like in shape and have a smaller size than MCC (Table 3) [34]. This material can be used to produce low-cost, lightweight and very strong nanocomposites due to its interesting properties [41] (Table 3).

\subsubsection{Cellulose derivatives}

Since native cellulose is neither meltable nor soluble in water or common organic solvents due to its highly crystalline structure, cellulose-based gels/films have limited applications. To form soluble cellulose, chemical modification of the cellulose surface is required. Etherification or esterification is a common process that can transform native cellulose into watersoluble cellulose. This modified cellulose is known as cellulose ether or ester (cellulose derivative products), has been reported as an environmentally friendly product and is useful in wide range of applications [24, 43-45]. Methylcellulose (MC), hydroxypropyl cellulose (HPC), hydroxypropyl methylcellulose (HPMC) and carboxymethyl cellulose (CMC) are common cellulose ethers manufactured by etherification of water-insoluble cellulose with methyl chloride (chloromethane), propylene oxide or monochloroacetate (chloroacetic acid) [22, 46]. In addition, cellulose acetate (CA), cellulose acetate phthalate (CAP), cellulose acetate butyrate (CAB), cellulose acetate trimellitate (CAT) and hydroxypropyl methylcellulose phthalate (HPMCP) are common cellulose ester derivatives that have been used in commercial products or in pharmaceutical investigations [33]. In addition, ionic liquids (ILs), which are advanced green solvents, have been extensively used as the

Table 3. The differences between MFC, MCC and NCC [32, 34, 36-41]

\begin{tabular}{|c|c|c|c|}
\hline & MFC & MCC & $\mathrm{NCC}$ \\
\hline Source & Pulp & $\begin{array}{l}\text { Native cellulose material (cotton } \\
\text { linter) or pulp }\end{array}$ & Microcrystalline cellulose \\
\hline Process & $\begin{array}{l}\text { Mechanical, Chemical-mechanical or } \\
\text { Enzymatic-mechanical }\end{array}$ & Strong acid hydrolysis & Sonication \\
\hline Size & $\begin{array}{l}\text { Diameter: } 5-60 \mathrm{~nm} \\
\text { Length: several } \mu \mathrm{m}\end{array}$ & $\begin{array}{l}\text { Diameter: } 10-50 \mu \mathrm{m} \\
\text { Length: } 1-10 \mu \mathrm{m}\end{array}$ & $\begin{array}{l}\text { Diameter: } 2-20 \mathrm{~nm} \\
\text { Length: } 100-600 \mathrm{~nm}\end{array}$ \\
\hline Structure & $\begin{array}{l}\text { Semi-crystalline cellulose } \\
\text { (long and flexible cellulose microfibrils) }\end{array}$ & $\begin{array}{l}\text { Rod-like cellulose microcrystals } \\
\text { (Microcrystalline fibril bundles) }\end{array}$ & $\begin{array}{l}\text { Rod-like cellulose nanocrystals } \\
\text { (long and straight cellulose } \\
\text { whiskers) }\end{array}$ \\
\hline Crystallinity & $51-69 \%$ & $80-85 \%$ & $54-88 \%$ \\
\hline Mechanical properties & $\begin{array}{l}\text { Elastic modulus: } \sim 140 \mathrm{GPa} \\
\text { Tensile strength: } 2-3 \mathrm{GPa}\end{array}$ & Elastic modulus: $25 \mathrm{GPa}$ & $\begin{array}{l}\text { Elastic modulus: } 110-200 \mathrm{GPa} \\
\text { Tensile strength: } 7.5-7.7 \mathrm{GPa}\end{array}$ \\
\hline
\end{tabular}


media in the modification of cellulose. Past research has found that cellulose can be dissolved in ionic liquids, which created a new approach for the development of a class of cellulose solvent systems [47]. Generally, ionic liquids are organic salts composed of cations and anions. The most common examples of organic cations are alkylimidazolium $\left[\mathrm{R}_{1} \mathrm{R}_{2} \mathrm{IM}\right]^{+}$, alkylpyridinium $[\mathrm{RPy}]^{+}$, tetraalkylammonium $\left[\mathrm{NR}_{4}\right]^{+}$ and tetraalkylphosphonium $\left[\mathrm{PR}_{4}\right]^{+}$. Anions, such as hexafluorophosphate $\left[\mathrm{PF}_{6}\right]^{-}$, tetrafluoroborate $\left[\mathrm{BF}_{4}\right]^{-}$, nitrate $\left[\mathrm{NO}_{3}\right]^{-}$, methanesulphonate $\left[\mathrm{CH}_{3} \mathrm{SO}_{3}\right]^{-}$, trifluoromethane sulfonate $\left[\mathrm{CF}_{3} \mathrm{SO}_{3}\right]^{-}$, and bis-(trifluoromethanesulphonyl) amide $\left[\mathrm{Tf}_{2} \mathrm{~N}\right]^{-}$, as well as various low melting chloride, bromide, and iodide salts, can be used in combination with the above cations [48]. The dissolution mechanism of cellulose in ionic liquids involves the $\mathrm{OH}$ group of cellulose forming electron donor-electron acceptor (EDA) complexes, which interact with the ionic liquid. The cellulose oxygen atoms serve as electron pair donors, and hydrogen atoms act as electron acceptors, whereas the cations in the ionic liquid solvent acts as electron acceptor centres, and anions act as electron-donor centres. During the reaction between cellulose-OH and the ionic liquid, the hydrogen bonding network of cellulose is interrupted, thus resulting in the dissociation of the hydrogen bonds between the molecular chains of cellulose. Finally, the cellulose dissolves [47]. This new cellulose material can be applied to the preparation of cellulose composites for thin films or beads in bioassays and supported reaction media, cellulose-based ion gel in fuel cells, biosensors and separation membranes, and electrospinning cellulosic fibres for biomedical applications [49].

\subsection{Bacterial cellulose}

Bacterial cellulose (BC), otherwise known as microbial cellulose or bio-cellulose, is formed by aerobic bacteria such as acetic acid bacteria of the genus Gluconacetobacter (i.e., Acetobacter xylinum). BC is a purely cellulose polymer, and no chemical treatments are needed for cellulose isolation. It is a unique and interesting material because it has both excellent mechanical strength and degradability compared to green plant cellulose. Moreover, BC has ribbonshaped fibrils, which are approximately $20-100 \mathrm{~nm}$ in diameter and are composed of much finer $2-4 \mathrm{~nm}$ nanofibrils. Therefore, this material is also commonly referred to as bacterial nanocellulose (BNC). Moreover, BNC is mainly produced by bacteria through biosynthesis and the building up of bundles of microfibrils, as opposed to the methods for obtaining nanocellulose through mechanical or chemo-mechanical processes $[34,36]$. These microfibril bundles have high crystallinity (84-89\%) and an elastic modulus of $78 \mathrm{GPa}$. They also possess a higher water holding capacity, a higher degree of polymerization (4000-6000) and a finer web-like network than the cellulose from plants. Because of these excellent properties, $\mathrm{BC}$ has a wide range of applications from food to functional materials such as diaphragms in speakers and headphones, electronic devices, wound dressings, additives in paper, membrane filters and more $[34,36,50,51]$.

\section{Biodegradable polymer film}

A biodegradable polymer film is a uniform layer of film that can be formed either from a single component or from a mixture of biopolymers (polysaccharides, proteins and lipids). Among the edible and degradable polymers, polysaccharide is the most promising edible polymer as it is inexpensive, abundantly available, biocompatible and environmentally friendly. Polysaccharides such as cellulose, starch and chitosan are natural renewable sources of polysaccharide and have been commonly manufactured into edible films due to their hydrocolloidal characteristics. Recently, seaweed has received much interest and attention as a film-forming material.

\subsection{Seaweeds: A source of biodegradable polymer matrices}

Alginate, carrageenan and agar are naturally occurring polysaccharides extracted from different types of seaweed. They have been extensively used as precursors for film-forming materials. Edible films made from seaweeds are nontoxic, degradable and biocompatible, and they demonstrate high rigidity and low deformability. However, films produced by seaweed have poor water vapour barrier properties due to seaweed's hydrophilic nature $[7,18]$. Since the preparation of film from a single polymer material exhibits both advantages and disadvantages, a combination of two polymer components can improve the desired characteristics, exploit their useful properties and widen their applications. Table 4 shows the incorporation of other components into the seaweed matrix.

Among the seaweed derivatives, alginate is the most investigated film-making material. Although algi- 
Table 4. The incorporation of other components into seaweed matrix

\begin{tabular}{|c|c|c|c|}
\hline Seaweed & $\begin{array}{c}\text { Other components/ } \\
\text { plasticizer added }\end{array}$ & Film characteristics and improvements & References \\
\hline \multirow{7}{*}{ 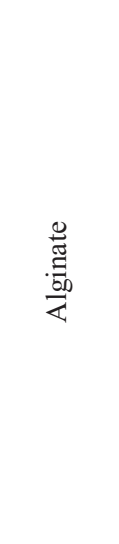 } & Calcium Chloride/glycerin & The film becomes water resistant by immersing alginate film in $\mathrm{CaCl}_{2}$ solutions. & [19] \\
\hline & $\begin{array}{l}\text { Apple puree and essential } \\
\text { oil }\end{array}$ & $\begin{array}{l}\text { The film exhibits antibacterial activity. No adverse effect of the additives on water } \\
\text { vapor \& oxygen permeability. }\end{array}$ & [52] \\
\hline & $\begin{array}{l}\begin{array}{l}\text { Sago starch and lemongrass } \\
\text { oil/glycerol }\end{array} \\
\end{array}$ & $\begin{array}{l}\text { The film exhibits antibacterial activity. The addition of lemongrass oil and glycerol } \\
\text { decrease mechanical properties \& increase water vapor permeability. }\end{array}$ & [53] \\
\hline & Montmorillonite (MMT) & $\begin{array}{l}\text { Film with low water solubility\& water vapor permeability and high mechanical } \\
\text { properties. }\end{array}$ & [54] \\
\hline & $\begin{array}{l}\text { Cinnamon bark oil and } \\
\text { soybean oil/glycerol }\end{array}$ & $\begin{array}{l}\text { The addition of these oils improves film microstructure homogeneity, transparency \& } \\
\text { antibacterial activity, while reduce film mechanical properties \& water solubility. }\end{array}$ & [55] \\
\hline & $\begin{array}{l}\text { Kappa- and Iota- } \\
\text { carrageenan/glycerol }\end{array}$ & $\begin{array}{l}\text { The addition of K-carrageenan improves moisture barrier\& overall tensile properties } \\
\text { of film. The addition of I-carrageenan impairs those properties of film. }\end{array}$ & [21] \\
\hline & $\begin{array}{l}\text { Silver } \\
\text { nanoparticles/glycerol }\end{array}$ & $\begin{array}{l}\text { The additions of silver particles improve the mechanical strength and water vapor } \\
\text { barrier properties of film. This film exhibits a UV screening effect \& strong antimi- } \\
\text { crobial activity. }\end{array}$ & [56] \\
\hline \multirow{6}{*}{ 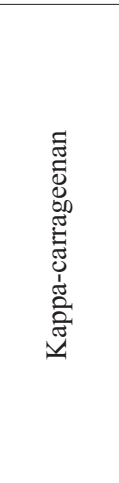 } & $\begin{array}{l}\text { Grapefruit seed extract } \\
\text { (GSE)/glycerol }\end{array}$ & $\begin{array}{l}\text { Yellowish tint \& great antibacterial activity film. The addition of GSE increases the } \\
\text { moisture content, water vapor permeability \& surface hydrophilicity, but decreases } \\
\text { tensile strength \& elastic modulus of film. }\end{array}$ & [57] \\
\hline & $\begin{array}{l}\text { Zataria multiflora essential } \\
\text { oil \& nanoclay/glycerol }\end{array}$ & The mechanical, antimicrobial and barrier properties of film are improved. & {$[58]$} \\
\hline & $\begin{array}{l}\text { Clay mineral \& silver } \\
\text { particles/glycerol }\end{array}$ & $\begin{array}{l}\text { The nanocomposite film improves on the mechanical \&water vapor barrier proper- } \\
\text { ties as well as antimicrobial activity. }\end{array}$ & [59] \\
\hline & $\begin{array}{l}\text { Essential oil/glycerol } \\
\& \text { PEG }\end{array}$ & $\begin{array}{l}\text { The addition of essential oil reduces water vapor permeability, tensile strength, mois- } \\
\text { ture absorption and increases transparency of film. }\end{array}$ & [60] \\
\hline & Chitin nanofibrils (CNF) & $\begin{array}{l}\text { The film shows transparent, strong antibacterial activity and improved mechanical } \\
\text { properties. }\end{array}$ & [61] \\
\hline & $\begin{array}{l}\text { Silver nanoparticles }(\mathrm{Ag}) \& \\
\text { PVP/PEG }\end{array}$ & $\begin{array}{l}\text { Addition of nanoparticles exhibit higher thermal stability, strength properties, an- } \\
\text { timicrobial activity \& lower swelling behavior of film. }\end{array}$ & [62] \\
\hline \multirow{7}{*}{ 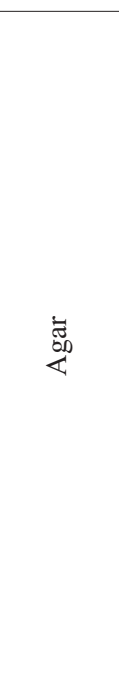 } & Arabinoxylan/glycerol & $\begin{array}{l}\text { The addition of arabinoxylan improves moisture barrier efficiency, but decreases } \\
\text { mechanical properties of film. }\end{array}$ & [3] \\
\hline & Starch/glycerol & $\begin{array}{l}\text { The addition of starch degrades surface resistance to water wetting \& mechanical } \\
\text { properties of film. }\end{array}$ & [3] \\
\hline & Silver (Ag) nanoparticles & $\begin{array}{l}\text { The film exhibits good mechanical stability, water vapor and gas barrier as well as } \\
\text { strong antimicrobial activity. }\end{array}$ & {$[63,64]$} \\
\hline & Nanoclay/glycerin & $\begin{array}{l}\text { Incorporation of clay (up to } 10 \% \text { ) increases the tensile strength and decreases the } \\
\text { water vapor permeability. }\end{array}$ & [65] \\
\hline & $\begin{array}{l}\text { Grapefruit seed extract } \\
\text { (GSE) }\end{array}$ & $\begin{array}{l}\text { The addition of GSE increases the color, UV barrier, moisture content, water solu- } \\
\text { bility \& water vapor permeability, but decreases the surface hydrophobicity, tensile } \\
\text { strength \& elastic modulus of film. The film exhibits distinctive antimicrobial ac- } \\
\text { tivity. }\end{array}$ & [57] \\
\hline & $\begin{array}{l}\text { Banana powder and Silver } \\
\text { (Ag) nanoparticles/glycerol }\end{array}$ & $\begin{array}{l}\text { The addition of banana powder increases the UV light absorption, water vapor bar- } \\
\text { rier property \& antioxidant activity, but decreases the mechanical properties of bi- } \\
\text { layer film. The composite film exhibits distinctive antimicrobial activity\& mechan- } \\
\text { ical properties. }\end{array}$ & [66] \\
\hline & $\begin{array}{l}\text { Fish gelatin and } \mathrm{TiO}_{2} \\
\text { nanoparticles }\end{array}$ & $\begin{array}{l}\text { The addition of } \mathrm{TiO}_{2} \text { decreases water vapor permeability and increases tensile } \\
\text { strength, UV light barrier property, swelling ratio \& moisture content of film. }\end{array}$ & [67] \\
\hline
\end{tabular}

nate films are strong, they exhibit poor water resistance because of their hydrophilic nature $[1,22]$. The ability of alginate to make strong and insoluble gels improves with the addition of calcium. However, gel formation of alginate with calcium ions is so instantaneous that it hinders film casting in some cases. Thus, several strategies have been proposed to solve this problem, such as immersing the alginate film in $\mathrm{CaCl}_{2}$ solution, blending alginate with natural polymers, adding hydrophobic compounds, crosslinking and using nanoreinforcements to produce bionano- composites (Table 4) $[19,54,101]$. Past research has shown that the addition of nanoparticles, such as clay and silver nanoparticles, into the alginate matrix can enhance the mechanical strength and water vapour barrier properties. Moreover, interest in antimicrobial films has risen recently due to the increased consumption of fresh-cut produce. With minimal processing, spoilage and pathogenic microorganisms can contaminate fresh foods. Many studies have verified that alginate films prepared with essential oils such as cinnamon bark oil, soybean oil, lemongrass oil and 
garlic oil, show higher antibacterial activity (Table 4). The antimicrobial properties of essential oils and their generally recognized-as-safe regulatory status have attracted much interest for their incorporation in edible films [52]. Furthermore, other hydrocolloids in matrices mixed with seaweed can form homogenous composite films, for instance carrageenan-alginate blend films. Kappa-carrageenan and alginate resulted in an interesting blend film, in which kappacarrageenan improved the moisture barrier and tensile properties of the alginate film [21].

Recent studies have focused on the application of degradable films to food surfaces to prevent the diffusion of preservative into food and inhibit surface microbial growth (Table 4). Although there are many available antimicrobial agents, natural antimicrobial agents obtained from plants, such as plant seed extract and essential oils, are particularly attractive in the food packaging industry due to their promising antibacterial, antifungal and antioxidant properties. Nevertheless, the incorporation of these antimicrobial agents reduces the tensile strength as well as the water vapour barrier properties of carrageenan films (Table 4). Hence, some studies have proposed that adding nanoparticles such as nanoclay, silver nanoparticles and chitin nanofibrils into the carrageenan matrix can reduce the water vapour permeability, while increasing the mechanical properties of the carrageenan film (Table 4). In addition, carrageenan has also been blended with other carbohydrate components such as starch to form an edible film. Although starch/carrageenan blend films have suitable mechanical properties overall, this blend film provides a minimal barrier to moisture due to the hydrophilic properties of starch and carrageenan polymers. Thus, polysaccharide based films usually exhibit poor water vapour barrier properties [68].

Similar to carrageenan, agar is also a galactose-based polysaccharide extracted from red seaweed and has a similar chemical structure of repeating disaccharide units. Agar and carrageenan are linear polysaccharides made up of alternating $\beta$-(1,3)- and $\alpha$ - $(1,4)$ linked galactose residues. Nevertheless, agar differs from carrageenan in that the $\alpha$ - $(1,4)$-linked residues in agars are the L-enantiomers, whereas in carrageenan, they are the D-enantiomers [69]. Although there is a chemical similarity between agar and carrageenan, the properties of edible films produced from these polymers are significantly different. Rhim [69] has reported that the tensile strength, swelling ratio and water solubility of carrageenan film is higher than that of agar film, whereas the water vapour permeability of the agar film is the lowest.

Generally, the mixture of seaweed and other carbohydrates can form a homogenous composite film, but that is not the case for agar film. With the incorporation of other polysaccharide components, such as starch and arabinoxylan, into degradable agar, the mechanical properties of the agar film degraded [3]. Alternatively, with the addition of agar to a starch film, the thermal, mechanical and water vapour barrier properties of this biocomposite film significantly improved [70, 71]. This phenomenon shows that agar is able to provide a suitable cohesive matrix, which contributes to the enhancement of other polysaccharide-based film properties. Similar to carrageenan films, agar films containing antimicrobial agents and nanoparticle additives often perform the additional function of improving the mechanical, barrier and antimicrobial properties of the film (Table 4).

\subsection{Cellulose: A biodegradable polymer reinforcement component}

Similar to other polysaccharides, cellulose is a potential film-forming material due to the high molecular weight of the glucose polymer. Since cellulose possesses a highly crystalline structure and hydrogen bonds, it is neither meltable nor soluble in water or common organic solvents. Therefore, it cannot form a gel/film in its natural state. Hence, modifications of cellulose are often carried out to transform it into water-soluble materials, known as cellulose derivatives.

Cellulose derivative films have good oxygen and aroma barrier properties, but poor water vapour barrier properties due to the inherent hydrophilic nature of polysaccharides, and they also possess poor mechanical properties $[22,46]$. One method in enhancing the moisture barrier is by incorporating hydrophobic compounds, such as fatty acids, essential oils and beeswaxes, into the cellulose derivative matrix to develop a composite film $[1,22,72-76]$. However, there are difficulties in preparing a homogenous composite film with both hydrophobic and hydrophilic compounds.

Therefore, previous studies have reported that the chemical modification of water-soluble cellulose derivatives into water-insoluble cellulose derivatives, for instance by crosslinking HPMC with citric acid can also increase the moisture barrier properties [77]. 
In addition, the mechanical properties of the cellulose film increase when the thickness and/or molecular weight of cellulose are increased. However, the mechanical properties, except the elongation at break of these films decreased due to the increase in plasticizer concentration (to enhance pliability of the film). Interestingly, recent research found that adding a reinforcing agent such as nanoparticles (i.e., nanoclay) could enhance the strength of cellulose-derivative films [27, 75, 78]

Apart from using chemically modified cellulose as a film precursor, cellulose and its derivatives have gained significant interest as reinforcement materials in degradable polymers, attracting attention in recent research and from industrial communities. Cellulose reinforcement is mainly applied to strengthen the polymer matrix structure, and meanwhile, a new composite material is created that has different physical properties and many new and interesting characteristics. Biodegradable polymer films usually have limitations such as poor mechanical, thermal and barrier properties compared to conventional nondegradable polymers made from petroleum $[43,79$, 80]. It is well known that the incorporation of cellulose and/or cellulose derivatives into a degradable polymer film can reduce such drawbacks to obtain mixed materials with desirable functions and properties

Recently, biodegradable composite films prepared using a mixture of hydrocolloids has been widely studied due to the chemical similarities of the hydrocolloids, which provide beneficial interactions and thus significantly improve the film properties. Previous studies have also shown that the mixture of cellulose with other polysaccharides can form a homogenous biocomposite film. A list of selected cellulose materials recently used as reinforcement components in polysaccharide-based films is summarized in Table 5.

Most recently, micro/nanoscale cellulose has generated great interest in the reinforcement of biocomposite materials due to its good mechanical and water

Table 5. Cellulose and cellulose derivatives in polysaccharides-based film

\begin{tabular}{|c|c|c|c|c|}
\hline Types of cellulose added & $\begin{array}{l}\text { Polysaccharides-based } \\
\text { film }\end{array}$ & $\begin{array}{c}\text { Crosslinking } \\
\text { agent/Plasticizer }\end{array}$ & Film improvements & References \\
\hline \multirow{2}{*}{$\begin{array}{l}\text { Microcrystalline cellulose } \\
\text { (MCC) }\end{array}$} & Starch & $\begin{array}{l}\text { Sorbitol and } \\
\text { Glycerol }\end{array}$ & $\begin{array}{l}\text { The stiffness, thermal stability \&resistance to } \\
\text { humidity absorption of film are improved. }\end{array}$ & [82] \\
\hline & Starch & $\begin{array}{l}\text { Acetic } \\
\text { acid/Glycerol }\end{array}$ & Mechanical properties of film are improved. & [10] \\
\hline \multirow{5}{*}{$\begin{array}{l}\text { Nanocrystalline cellulose } \\
(\mathrm{NCC})\end{array}$} & Chitosan & Acetic acid & $\begin{array}{l}\text { Mechanical performance \& hydrophobicity of } \\
\text { film are improved. }\end{array}$ & [83] \\
\hline & Starch & $\begin{array}{l}\text { Glycerol and } \\
\text { Lignin }\end{array}$ & $\begin{array}{l}\text { Mechanical, thermal \& barrier properties of film } \\
\text { are improved. }\end{array}$ & [84] \\
\hline & Carboxymethyl Cellulose & Glycerol & $\begin{array}{l}\text { Mechanical \& water vapor barrier properties of } \\
\text { film are improved. }\end{array}$ & [85] \\
\hline & Gellan gum & Glycerol & $\begin{array}{l}\text { Mechanical \& barrier properties of film are } \\
\text { improved. }\end{array}$ & [43] \\
\hline & Tara gum & Glycerol & $\begin{array}{l}\text { Addition of NCC achieves the highest light } \\
\text { transmittance, mechanical properties \&the } \\
\text { lowest oxygen permeability of film. }\end{array}$ & [26] \\
\hline \multirow{3}{*}{$\begin{array}{l}\text { Nanofibrillated cellulose } \\
(\mathrm{NFC})\end{array}$} & Starch & Glycerol & $\begin{array}{l}\text { Addition of nanofillers up to } 10 \% \text { increase } \\
\text { mechanical \&moisture barrier properties of }\end{array}$ & [86] \\
\hline & Chitosan & Acetic acid & $\begin{array}{l}\text { Mechanical and thermal stability properties of } \\
\text { film are improved. }\end{array}$ & {$[37,87]$} \\
\hline & Carboxymethyl Cellulose & Glycerol & $\begin{array}{l}\text { Addition of CNF up to } 5 \mathrm{wt} \% \text { improves } \\
\text { mechanical strength, water vapor barrier } \\
\text { properties \& thermal stability of film. }\end{array}$ & [88] \\
\hline \multirow{4}{*}{$\begin{array}{l}\text { Carboxymethyl Cellulose } \\
\text { (CMC) }\end{array}$} & Starch & $\begin{array}{l}\text { Citric acid and } \\
\text { Glycerol }\end{array}$ & $\begin{array}{l}\text { Film with good physical-mechanical, optical } \\
\text { properties and moisture resistance. }\end{array}$ & [11] \\
\hline & Starch & Citric acid & $\begin{array}{l}\text { Film with good water vapor barrier properties } \\
\text { and ultimate tensile strength. }\end{array}$ & [89] \\
\hline & Chitosan & Acetic acid & $\begin{array}{l}\text { Film with good tensile strength, thermos- } \\
\text { stability \& water resistance. But, film with poor } \\
\text { oxygen permeability, light transmittance \& } \\
\text { antibacterial activity. }\end{array}$ & [81] \\
\hline & Bacterial Cellulose (BC) & $\begin{array}{l}\text { Sorbitol and } \\
\text { Glycerol }\end{array}$ & $\begin{array}{l}\text { Film with good transparency and mechanical } \\
\text { properties. }\end{array}$ & [51] \\
\hline
\end{tabular}


barrier properties. NFC, MCC and NCC are common cellulose ingredients in polysaccharide-based films. Since the thick middle layer in the plant cell wall determines the mechanical properties of the fibre, the incorporation of these micro/nanoscale fibres largely improve the mechanical performance of the composite films (Table 5). In the microfibrils in the cell wall, cellulose is arranged in both amorphous and crystalline regions. In general, crystalline cellulose is much stronger and stiffer than amorphous cellulose. Therefore, MCC and NCC are widely used to reinforce various biopolymer materials, compared to NFC, due to their high crystallinity (Table 3), which can enhance the mechanical properties of the resulting biocomposites. Such improvement can be expected when MCC or NCC reinforces other polysaccharides (i.e., starch) film because of the chemical similarities in both of the polysaccharide structures, which encourages the formation of hydrogen bonds between the components [82]. Although both MCC and NCC are crystalline, NCC is more promising than $\mathrm{MCC}$ as a reinforcement material in some edible films due to its nanoscale dimensions providing a proportionally larger surface area that can enhance the reinforcement effects in the polymer matrix composites (Table 3) [26, 43].

Carboxymethyl cellulose (CMC) is the most important cellulose-derived hydrocolloid and is widely used as a stabilizer in food and as an additive in packaging material [90]. In addition, CMC is a common cellulose derivative ingredient in polysaccharidebased films and has no harmful effect on human health. CMC exhibits a strong barrier against oxygen, carbon dioxide, and lipids, and thus it has been used as a highly effective additive to improve the properties of films. Previous studies have reported that polysaccharide blend films with CMC can have excellent mechanical and barrier properties due to the chemical similarity of the polysaccharides, which allows for better compatibility (Table 5) [22, 81, 88].

\subsection{Seaweed matrix blends with cellulose reinforcement}

Seaweed and cellulose are ideal starting materials in diverse applications. The use of seaweed and cellulose in composite materials has been of scientific interest in recent years. Although seaweed films have strong potential for use in a wide range of applications, they typically lack sufficient mechanical properties, such as high strength. Since cellulose exhibits outstanding mechanical properties, it is a promising reinforcement material for improving the composite performance through its interesting characteristics, as discussed earlier. Previous studies have also reported that the addition of hydrocolloid into a polysaccharide film can improve the limitations of the film. Seaweed/cellulose composite films have been recently studied, as shown in Table 6 . Blending seaweed and cellulose improves the properties and maximizes the composite performance in a wide range of applications, such as food packaging, biomedical applications and pharmaceutical-based materials.

\subsubsection{Preparation of seaweed/cellulose blends film}

Many researchers have studied seaweed/cellulose blend films obtained by the solvent-casting method. The complete film-forming process can be divided into several steps: polymer gelatinization and dispersion, homogenization of the mixture, casting and drying. This method is commonly known as a wet process [108]. In general, there is no standard method to prepare certain films with required functions and properties. Thus, the preparation of seaweed/cellulose composite films is a process that depends on the type of seaweed, cellulose and plasticizer.

When dry raw seaweed is used to prepare an edible seaweed film, the seaweed is usually washed under running water to remove debris and salt before being soaked. The seaweed soaks and disperses in water in order to form moderately stable suspensions. After soaking, gelatinized seaweed is formed. Lastly, the seaweed solution is poured on the fabricated casting plates and subsequently dried [109]. Alternatively, when alginates, carrageenans and agars, which are seaweed derivatives, are used to prepare an edible seaweed film, they are usually dissolved in water and heated under stirring to form a gel-like material (without soaking) because they are water-soluble polymers and are extracted from seaweed [98].

In most cases, the seaweed film may become brittle during aging, which is undesirable. Therefore, plasticizers are generally added to the seaweed dispersions before film formation to overcome this limitation [98]. The main advantage of using plasticizers is that the film becomes more flexible (elongation at break increases); however, tensile strength (TS) decreases, as seen in the data shown in Table 6 . An effective plasticizer must be compatible with the polymer matrix. Among the plasticizers, glycerol is one 
Table 6. The performances and applications of various seaweed/cellulose composite films by casting

\begin{tabular}{|c|c|}
\hline Seaweed/Cellulose/Others & Film characteristics, improvements $\&$ applications \\
\hline Alginate/NCC [9] & $\begin{array}{l}\text { Incorporation of NCC improves film mechanical (except elongation), water vapor } \\
\text { permeability \& thermal properties. } \\
\text { Application: food packaging }\end{array}$ \\
\hline $\begin{array}{l}\text { Alginate/Cellulose whickers/acerola puree } \\
\text { and corn syrup [91] }\end{array}$ & $\begin{array}{l}\text { Incorporation of cellulose whiskers improves film tensile strength, elastic modulus \& water } \\
\text { vapor barrier. } \\
\text { Application: edible coating }\end{array}$ \\
\hline $\begin{array}{l}\text { Alginate/MFC/Chitosan-benzalkonium } \\
\text { Chloride crosslinking with TPP [92] }\end{array}$ & $\begin{array}{l}\text { Incorporation of CMF/C-BC composite improves film antibacterial \& strength properties. } \\
\text { Application: food packaging }\end{array}$ \\
\hline Alginate/NCC/Glycerol [54] & $\begin{array}{l}\text { Incorporation of up to } 5 \% \text { NCC increases tensile strength of film. } \\
\text { Application: food packaging }\end{array}$ \\
\hline $\begin{array}{l}\text { Alginate/CMC/crosslinking with } \\
\text { Graphene oxide [93] }\end{array}$ & $\begin{array}{l}\text { The composite exhibit high storage modulus, tensile strength \& Young's modulus. } \\
\text { Application: pharmaceutical devices }\end{array}$ \\
\hline $\begin{array}{l}\text { Alginate/Cellulose }(19.0 \mu \mathrm{m}- \\
25 \mathrm{~nm}) / \text { crosslinking with calcium [94] }\end{array}$ & $\begin{array}{l}\text { The composite show excellent grease barrier properties \& reduction in water vapor } \\
\text { permeability (Except unmodified pulp). } \\
\text { Application: packaging materials. }\end{array}$ \\
\hline $\begin{array}{l}\text { Alginate/Carboxymethylated } \\
\text { BC/crosslinking with calcium [95] }\end{array}$ & $\begin{array}{l}\text { The composite has dramatically improved in the swelling, thermal \& mechanical } \\
\text { properties. } \\
\text { Application: wound dressings and skin tissue engineering }\end{array}$ \\
\hline Alginate/BC/Silver sulfadiazine [96] & $\begin{array}{l}\text { The composite has an excellent antibacterial activities \& good biocompatibility. } \\
\text { Application: wound dressings }\end{array}$ \\
\hline Alginate/CMC/Silver sulfadiazine [97] & $\begin{array}{l}\text { The film exhibits better swelling time. } \\
\text { Application: hydrogel film }\end{array}$ \\
\hline Alginate/NFC/Glycerol [98] & $\begin{array}{l}\text { Incorporation of CNF improves film water resistance \&mechanical properties, decreases } \\
\text { biodegradation time. } \\
\text { Application: food packaging }\end{array}$ \\
\hline Alginate/NCC [99] & $\begin{array}{l}\text { The hybrid hydrogels exhibited desired mechanical properties and improve resistance to } \\
\text { biodegradation. } \\
\text { Application: hydrogel film }\end{array}$ \\
\hline $\begin{array}{l}\text { Carrageenan/NFC/crosslinking with } \\
\text { gelatin [100] }\end{array}$ & $\begin{array}{l}\text { Addition of CNF improves the tensile strength, water vapor transmission rate \& oxygen } \\
\text { transmission rate of film. } \\
\text { Application: food packaging }\end{array}$ \\
\hline $\begin{array}{l}\text { Carrageenan/CMC/Nanoclay, glycerol } \\
{[102]}\end{array}$ & $\begin{array}{l}\text { Hardness \& adhesiveness increase as the polymer concentration increase. } \\
\text { Application: soft gel capsules }\end{array}$ \\
\hline Carrageenan/CMC/Acetic acid [103] & $\begin{array}{l}\text { The blend of kappa-carrageenan \& cellulose derivatives exhibit good conductivity. } \\
\text { Application: biopolymer electrolytes }\end{array}$ \\
\hline Carrageenan/NCC/Glycerol [104] & $\begin{array}{l}\text { Incorporation of NCC (up to } 4 \% \text { ) shows good dispersion, superior mechanical properties \& } \\
\text { thermal stability of film. } \\
\text { Application: packaging material }\end{array}$ \\
\hline $\begin{array}{l}\text { Agar/MFC/Chitosan } \\
\text { methylisothiazolinone crosslinking with } \\
\text { TPP [105] }\end{array}$ & $\begin{array}{l}\text { Incorporation of MFC/C-MIT composite enhances film tensile property and excellent } \\
\text { antimicrobial activity. } \\
\text { Application: biomaterial }\end{array}$ \\
\hline Agar/NCC/Glycerol $[80,106]$ & $\begin{array}{l}\text { Film transparency decreased. Addition of NCC improves film mechanical, thermal \& water } \\
\text { vapor barrier properties. } \\
\text { Application: food packaging }\end{array}$ \\
\hline $\begin{array}{l}\text { Agar/NCC/Savory essential oil and } \\
\text { Glycerol [107] }\end{array}$ & $\begin{array}{l}\text { Addition of savory oil decreases tensile strength } \& \text { increases water vapor permeability \& } \\
\text { opacity and improves antimicrobial property of film. } \\
\text { Application: food packaging }\end{array}$ \\
\hline
\end{tabular}

of the most commonly used plasticizers for film formation. The initial stage is always the gelatinization of the seaweed, or dispersion. The main reason for disrupted gelatinization is when an excess of water is present. Therefore, seaweed gelatinization always occurs at different temperatures, depending on the type of seaweed and the plasticizer content. Since glycerol is hydrophilic in nature, the seaweed is usually mixed together with or separately from the plasticizer by occasional stirring and heating.
Apart from that, the addition of micro/nanoscale cellulose as a reinforcement material in the seaweed film, besides improving the mechanical properties (i.e., tensile strength) of the seaweed film, also enhances the water vapour barrier properties of the film due to the hydrophobic character of cellulose (Table 6). However, in some cases, the mechanical properties of seaweed films such as the elongation at break show either no improvement or decreased performance with an increase in cellulose content, even in the 
presence of plasticizer (Table 6). Commonly, cellulose, seaweed and glycerol are mixed together by occasional stirring and heating. The solution is subsequently degassed to remove bubbles under vacuum. After that, the film-forming solution is cast onto a petri dish or a Teflon ${ }^{\circledR}$ plate. Then, it is dried in the oven at low temperature $\left(40^{\circ} \mathrm{C}\right)$ for approximately 24 hour or kept at room temperature until dry. The dry film is then removed from the casting plate and stored in a polyethylene bag prior to characterization $[9,98]$. Moreover, in order to reduce aggregation and obtain a good dispersion of the nanoparticles, the suspension of micro/nanoscale cellulose can be sonicated or homogenized using a high shear mixer before dispersion in the seaweed and plasticizer solution [80, 107]. This seaweed/cellulose composite film is commonly used as a packaging material, especially in the food industry (Table 6).

In contrast, carboxymethyl cellulose (CMC), a cellulose derivative, can be directly blended with seaweed derivatives and dissolved into distilled water by continuous stirring and heating due to both materials being water-soluble polymers. Moreover, chemical or ionic crosslinking agents are sometimes added to enhance the mechanical and barrier properties of the film $[93,97]$. The same behaviour is seen when $\mathrm{BC}$ is mixed with seaweed derivatives. These seaweed/cellulose blend films are commonly used as hydrogels and wound dressings and in membrane separation (Table 6).

\subsubsection{Compatibility between seaweed and cellulose}

Blending natural polymers with different properties can create novel composite materials with desirable properties for specific uses. It is well known that blending polymers can greatly influence both the physical and rheological properties of mixed solutions, likely due to the compatibility or incompatibility between the two macromolecules [3]. Compatibility is a technical term defining the properties profile of the blend film in view of a certain application. The compatibility of polymers is considered to be beneficial when the combination of properties is advantageous and desired. In contrast, polymers are incompatible when the blend properties are not desired. The compatibility of polymers depends on their molecular weight, chemical structures, conformations and hydration behaviours $[3,110]$.
It is expected that plant cellulose can improve the mechanical and barrier properties of seaweed films due to the chemical similarity of seaweed and cellulose, making them highly compatible $[9,54]$. Cellulose has three reactive hydroxyl groups, whereas seaweed has hydroxyl, carboxyl and sulphate groups [5, 111]. Therefore, cellulose readily interacts with seaweed by forming hydrogen bonds. Micro/nanoscale plant cellulose has been widely used as a reinforcement material in extracted seaweed matrices for the development of biodegradable food packaging materials. This cellulose is a hydrocolloid with no solubility in water and adsorbs at the interface. Past reports have shown that the incorporation of these cellulose materials into the seaweed matrix improved the mechanical properties, water vapour permeability and thermal properties of the seaweed film (Table 6). The improvement in mechanical strength is largely due to the good interfacial interaction (i.e., formation of tightly bound hydrogen bond networks) between the cellulose reinforcement material and the seaweed matrix, while the water barrier properties are enhanced due to the high crystallinity of cellulose, which leads to strong hydrogen bond networks and good dispersion within the seaweed [9, 94, 98]. Nevertheless, the mechanical and barrier properties of the film are only increased by increasing the amount of cellulose in the composite and by decreasing the fibre size of the cellulose (Table 6) [94]. Therefore, nanoscale cellulose is often used due to its larger surface area and increased number of surface atoms that can promote good dispersion compared with its microscale counterpart. Moreover, the use of sulfuric acid also imparts a negative charge on the nanocrystalline cellulose, which can prevent the nanocrystalline cellulose particles from aggregating (Figure 5). Hence, interactions between nanocellulose and the seaweed (hydrophilic) matrix are much stronger because of a percolated network that is connected via hydrogen bonds in the interphase region $[9,26,43]$. Plant cellulose and BC are chemically similar. However, the properties of $\mathrm{BC}$ are far more advantageous than those of plant cellulose. BC consists purely of cellulose and shows a peculiar, ultrafine fibre network with high water holding capacity and mechanical strength compared to plant cellulose. Therefore, chemical modification of plant cellulose is usually performed to produce cellulose derivatives, which are more easily processed and have many applications in 


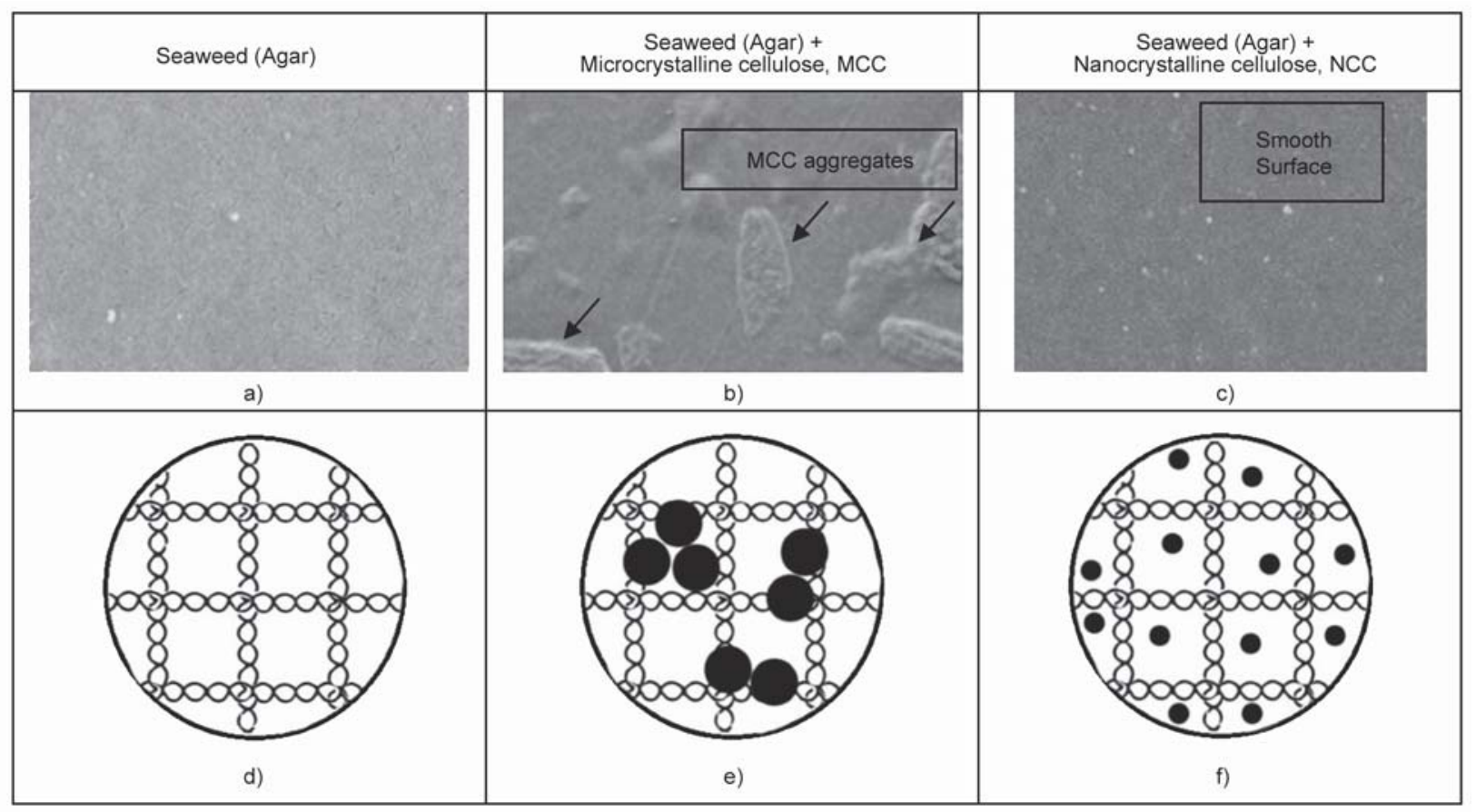

Figure 5. (a, b, c) Surface morphology and (d, e, f) schematic drawing of pure seaweed, seaweed blends with MCC and seaweed blends with NCC [80]

industry [112]. Previous studies have reported that $\mathrm{CMC}$ and $\mathrm{BC}$ have been extensively blended with seaweed for advanced applications. For example, in membrane separation, hydrogel films, biopolymer electrolytes, wound dressings, and biomedical and pharmaceutical devices (Table 6). Since CMC, BC and seaweed derivatives consist of various hydroxyl and carboxyl groups, they can form superior gel films upon chemical crosslinking (Table 6). Therefore, this phenomenon indicates good compatibility between seaweed and cellulose derivatives or $\mathrm{BC}$ due to their ability to create strong hydrogen bonds.

\subsubsection{Biodegradability of seaweed and cellulose}

Since most films made of synthetic polymers are resistant to degradation, recent research has focused on developing biodegradable polymer films. Biodegradable polymers can be degraded and ultimately catabolized to carbon dioxide and water by microorganisms (i.e., bacteria, fungi and algae) in the natural environment. Among the biodegradable polymers, polysaccharide is one of the natural biodegradable polymers that has been extensively investigated [113, 114].

Apart from chemical, mechanical, thermal and photochemical degradation methods, cellulose and its derivatives can be easily degraded by microorganisms present in air, water and soil [115]. It is known that cellulose can be degraded into glucose by cellulase (an enzyme) for bioethanol production [116]. The biodegradation rate of cellulose is dependent on the crystallinity of cellulose. Low crystallinity cellulose usually has a higher biodegradation rate [112]. Cellulose derivatives are less crystalline in comparison to dissolved pulp, micro/nanoscale cellulose and $\mathrm{BC}$ $[42,117,118]$. Therefore, the biodegradability of cellulose derivatives is much higher than that of other cellulose materials.

Seaweed is the best known natural polysaccharide found in marine environments. Similar to cellulose, it can be anaerobically digested for the production of bioethanol [119]. Among the polysaccharide-based polymers, seaweed can be fully degraded in the natural environment. Since the natural degradation process usually involves microorganisms from the soil whose activity requires nitrogen consumption, the biodegradability of materials without nutrients, such as cellulose and starch, is considered to be lower than that of seaweed [120]. Although using more biodegradable material (i.e., seaweed) would be better for the environment, this will lead to a faster degradation rate for the material and thus restricts its application. Hence, recent studies propose blending polymers to extend the biodegradation period. Seaweed blends with cellulose have significantly prolonged the shelf life of films due to the homogeneous dispersion and hydrophobicity of cellulose $[98,99]$. 


\subsubsection{Potential contribution of seaweed and cellulose in bioeconomy}

The bioeconomy, or the bio-based economy, is defined as an economy where the basic building blocks for materials, chemicals and energy are derived from renewable resources, such as plant and animal sources. The benefits of transitioning from a fossilbased to a bio-based economy include a reduction in greenhouse gas (GHG) emissions, decrease in the dependence on fossil resources, wiser management of natural resources, and improved food security [121]. Biodegradable polymer production has grown exponentially, driven by national and international environmentalists. The development of biodegradable polymers leads to the use of renewable feedstocks as the base material for multifaceted applications across various fields.

Cellulose is a sustainable and renewable biomass feedstock that can be obtained from wood and nonwood lignocellulosic biomasses. In the more environmentally friendly approach, non-wood cellulose has been widely used for various applications, for instance as fillers in composite materials, as absorbents and as pulp in paper making. Since non-wood cellulose has widespread and valuable use across industries, this resource provides sufficient supply and possesses economic value. Tye et al. [30] have reported that the global production of total cellulose from non-wood lignocellulosic biomass can reach to about one billion tons per annum (from three billion tons of non-wood lignocellulosic biomass). Hence, cellulose is profitable for manufacturing a wide range of innovative cellulose-based products due to its abundant availability.

In addition to the cost-effective polysaccharides derived from plant sources, seaweed is able to grow in a wide range of environments and is cost effective, easy to cultivate, obtained in the natural environment and abundantly available, giving it potential use in the bioeconomy. Seaweed farming is a common practise in many countries, with the produced seaweed being utilized in commercial uses such as the preparation of agar culture media, as food sources, and as thickening or stabilizing agents. Most recently, scientists have developed a biodegradable rope made from seaweed to replace the synthetic rope used to tie seedlings in seaweed farming. It was found that the rope made from seaweed extract could last for over 45 days in the field and over 6 months in sea water under laboratory conditions. Moreover, the tensile strength of the seaweed rope was higher $(65 \mathrm{MPa})$ than that of the synthetic rope and thus suitable to be utilized as a substitute [122]. Since seaweed has a huge potential market value and demand, it can improve the country's economy as well as the social livelihood of people living in the coastal areas, as they can earn more income from seaweed farming.

Both seaweed and cellulose are cost-effective materials; it is believed that seaweed-cellulose blends can form profitable and biodegradable composite films with a wide range of uses. Cellulose can replace the montmorillonite and silver nanoparticles that are usually added in seaweed film to enhance the mechanical properties of the film (Tables 4 and 6). Cellulose is rather inexpensive, environmentally friendly and degradable compared to these nanoparticles. Among the polysaccharides, starch is a common film-making material in the food industry. Nevertheless, the overutilization of starches as film precursors has disrupted the food source. Seaweed is an alternative hydrocolloid that can also form films for food packaging, while maintaining the biodegradability and, meanwhile, reducing the overconsumption of starch from food sources. Therefore, these indicate that the utilization of both seaweed and cellulose materials have met the requirements of many applications. Hence, the development of seaweed/cellulose composite film has a huge potential for bioeconomy growth. Additionally, this composite film may has equal performance to or exceed the current performance of current composite materials.

\section{Future development of seaweed/cellulose composite film}

Throughout the review, seaweed/cellulose composite film has offered several advantageous, which is of great potential to food, medical and high end industries. However, the development of this composite film is still on the preliminary stage due to their uncertain function, quality and cost. To expand the application of seaweed-cellulose biocomposites across various industries, there are several aspects that must be considered for future development and application. Seaweed has been recognized as a good film-forming material. However, several studies utilized derivatives from seaweed (i.e. alginate, carrageenan and agar) instead of its original form for biodegradable film production. This is due to seaweed derivatives have better transparency, mechanical and water vapor barrier properties than the original form of sea- 
weed $[21,54,69,109]$. Therefore, seaweed derivatives have been widely used in high end medical and electrical applications such as polymer electrolytes, wound dressings, scaffolds, hydrogel for cell and drug delivery, biomedical and pharmaceutical devices as well as softgel capsules [93, 96-97, 99, 102, 103, 105]. Nevertheless, the production of these seaweed derivatives is not economically feasible and environmentally friendly as high chemical and energy consumption are used during extraction or isolation process. Hence, production of edible film directly from the original form of seaweed should be focused for future development and application.

Although the edible film produced from the untreated seaweed is relatively simple, environmentally friendly and cheaper than the seaweed derivatives do, seaweed in its original form has poor physicochemical properties, which limited its extensive application. As cellulose exhibits excellent mechanical performance, blending the untreated seaweed with cellulose can be an advantageous approach, which is feasible to improve the properties of this edible seaweed based film. An untreated seaweed blend with cellulose is a novel research, even though it has not yet been explored, but based on their different intrinsic properties, it is believed that the development of seaweed/cellulose composite films may possibly attain equal or even better performance than the seaweed derivative films.

In food industry, seaweed derivatives are widely used as gelling agent in processed foods. This polysaccharide also has significant potential for development as a source of biodegradable or edible film in packaging applications. However, seaweed derivatives exhibit some poor physical, mechanical, and thermal properties that are needed for food packaging applications. In this regards, cellulose especially in its nano-size form has been proposed as reinforcing agents in seaweed derivatives film, owing to its high tensile strength and modulus. Thus, this bionanocomposite-based film reveal remarkably improved in its properties as compared to the pure seaweed derivatives films $[91,100,107]$. Nevertheless, this bionanocomposite-based film has limited usage in some food packaging application, where in it cannot classified as edible food wrapper due to cellulose is considered non-edible materials. Although cellulose is found in all plants and is the most abundant carbohydrate in the world, humans cannot use cellulose as a food source because no vertebrate has the capacity to digest cellulose enzymatically. In contrast, herbivores have symbiotic bacteria in their intestinal tract that help them digest cellulose [123]. To expand seaweed/cellulose composite film in this application, recent research has successfully converted cellulose into an edible form material like starch, which the consumer can digest the food and food wrapper as well [124]. This amazing breakthrough has pioneered this 'modified cellulose' for future development in degradable and consumable food packaging. Hence, seaweed or its derivative blends with this 'modified cellulose' will be a new, innovative and multifunctional composite film, which should be researched for future development and application.

\section{Conclusions}

This review shows that seaweed and cellulose are potential film-forming polymeric materials. The study of seaweed and cellulose in regards to their compatibility, biodegradability and potential contribution to the bioeconomy have verified that seaweed and cellulose are compatible for forming biodegradable and cost-effective blend films for a wide range of applications. Hence, it is worth to further investigate this newly developed composite material in order to produce highly sustainable, functional and cost-effective products.

\section{Acknowledgements}

All the authors are gratefully acknowledged Ministry of Higher Education for the Fundamental Research Grant Scheme Malaysia's Rising Star Award 2015 (FRGS-203/PTEKIND/ 6711531).

\section{References}

[1] Shit S. C., Shah P. M.: Edible polymers: Challenges and opportunities. Journal of Polymers, 2014, 427259/1427259/13 (2014).

https://doi.org/10.1155/2014/427259

[2] Joye I. J., McClements D. J.: Biopolymer-based nanoparticles and microparticles: Fabrication, characterization, and application. Current Opinion in Colloid and Interface Science, 19, 417-427 (2014). https://doi.org/10.1016/j.cocis.2014.07.002

[3] Phan The D., Debeaufort F., Voilley A., Luu D.: Biopolymer interactions affect the functional properties of edible films based on agar, cassava starch and arabinoxylan blends. Journal of Food Engineering, 90, 548-558 (2009). https://doi.org/10.1016/j.jfoodeng.2008.07.023 
[4] Wang S., Marcone M. F., Barbut S., Lim L-T.: Fortification of dietary biopolymers-based packaging material with bioactive plant extracts. Food Research International, 49, 80-91 (2012).

https://doi.org/10.1016/j.foodres.2012.07.023

[5] Venkatesan J., Anil S., Kim S-K., Shim M. S.: Seaweed polysaccharide-based nanoparticles: Preparation and applications for drug delivery. Polymers, 8, 30/1-30/25 (2016). https://doi.org/10.3390/polym8020030

[6] Daemi H., Rajabi-Zeleti S., Sardon H., Barikani M., Khademhosseini A., Baharvand H.: A robust super-tough biodegradable elastomer engineered by supramolecular ionic interactions. Biomaterials, 84, 54-63 (2016). https://doi.org/10.1016/j.biomaterials.2016.01.025

[7] Gade R., Tulasi M. S., Bhai V. A.: Seaweeds: A novel biomaterial. International Journal of Pharmacy and Pharmaceutical Sciences, 5, 40-44 (2013).

[8] Sousa A. M., Alves V. D., Morais S., Delerue-Matos C., Gonçalves M. P.: Agar extraction from integrated multitrophic aquacultured Gracilaria vermiculophylla: Evaluation of a microwave-assisted process using response surface methodology. Bioresource Technology, 101, 3258-3267 (2010).

https://doi.org/10.1016/j.biortech.2009.12.061

[9] Huq T., Salmieri S., Khan A., Khan R. A., Tien C. L., Riedl B., Fraschini C., Bouchard J., Uribe-Calderon J., Kamal M. R., Lacroix M.: Nanocrystalline cellulose (NCC) reinforced alginate based biodegradable nanocomposite film. Carbohydrate Polymers, 90, 1757-1763 (2012).

https://doi.org/10.1016/j.carbpol.2012.07.065

[10] Sudharsan K., Mohan C. C., Babu P. A. S., Archana G., Sabina K., Sivarajan M., Sukumar M.: Production and characterization of cellulose reinforced starch (CRT) films. International Journal of Biological Macromolecules, 83, 385-395 (2016).

https://doi.org/10.1016/j.ijbiomac.2015.11.037

[11] Ghanbarzadeh B., Almasi H., Entezami A. A.: Physical properties of edible modified starch/carboxymethyl cellulose films. Innovative Food Science and Emerging Technologies, 11, 697-702 (2010). https://doi.org/10.1016/j.ifset.2010.06.001

[12] El-Said G. F., El-Sikaily A.: Chemical composition of some seaweed from Mediterranean Sea coast, Egypt. Environmental Monitoring and Assessment, 185, 60896099 (2013).

https://doi.org/10.1007/s10661-012-3009-y

[13] Fleurence J.: Seaweed proteins: Biochemical, nutritional aspects and potential uses. Trends in Food Science and Technology, 10, 25-28 (1999). https://doi.org/10.1016/S0924-2244(99)00015-1

[14] García-Casal M. N., Pereira A. C., Leets I., Ramírez J., Quiroga M. F.: High iron content and bioavailability in humans from four species of marine algae. Journal of Nutrition, 137, 2691-2695 (2007).
[15] Kraan S.: Algal polysaccharides, novel applications and outlook. in 'Carbohydrates - Comprehensive studies on glycobiology and glycotechnology' (ed.: Chang C. F.) InTech, Rijeka (2012).

https://doi.org/10.5772/51572

[16] Gholamipoor S., Nikpour-Ghanavati Y., Oromiehie A. R., Mohammadi M.: Extraction and characterization of alginate from Sargassum angustifolium collected from northern coasts of Persian Gulf, Bushehr. in " $7^{\text {th }}$ International Symposium on Advances in Science and Technology SASTech 2013. Bandar-Abbass, Iran' 1-5 (2013).

[17] Santos G. A.: A manual for the processing of agar from gracilaria. ASEAN/UNDP/FAO Regional Small-Scale Coastal Fisheries Development Project, Manila (1990).

[18] Tavassoli-Kafrani E., Shekarchizadeh H., MasoudpourBehabadi M.: Development of edible films and coatings from alginates and carrageenans. Carbohydrate Polymers, 137, 360-374 (2016).

https://doi.org/10.1016/j.carbpol.2015.10.074

[19] Rhim J-W.: Physical and mechanical properties of water resistant sodium alginate films. LWT-Food Science and Technology, 37, 323-330 (2004). https://doi.org/10.1016/j.lwt.2003.09.008

[20] Yang J-S., Xie Y-J., He W.: Research progress on chemical modification of alginate: A review. Carbohydrate Polymers, 84, 33-39 (2011). https://doi.org/10.1016/j.carbpol.2010.11.048

[21] Paula G. A., Benevides N. M. B., Cunha A. P., de Oliveira A. V., Pinto A. M. B., Morais J. P. S., Azeredo H. M. C.: Development and characterization of edible films from mixtures of $\kappa$-carrageenan, l-carrageenan, and alginate. Food Hydrocolloids, 47, 140-145 (2015). https://doi.org/10.1016/j.foodhyd.2015.01.004

[22] Dhanapal A., Sasikala P., Rajamani L., Kavitha V., Yazhini G. M., Banu M. S.: Edible films from polysaccharides. Food Science and Quality Management, 3, 917 (2012).

[23] Campo V. L., Kawano D. F., da Silva D. B., Carvalho I.: Carrageenans: Biological properties, chemical modifications and structural analysis - A review. Carbohydrate Polymers, 77, 167-180 (2009). https://doi.org/10.1016/j.carbpol.2009.01.020

[24] Arvanitoyannis I., Biliaderis C. G.: Physical properties of polyol-plasticized edible blends made of methyl cellulose and soluble starch. Carbohydrate Polymers, 38, 47-58 (1999). https://doi.org/10.1016/S0144-8617(98)00087-3

[25] Kalia S., Dufresne A., Cherian B. M., Kaith B. S., Avérous L., Njuguna J., Nassiopoulos E.: Cellulosebased bio- and nanocomposites: A review. International Journal of Polymer Science, 2011, 837875/1-837875/ 35 (2011). https://oi.org/10.1155/2011/837875 
[26] Ma Q., Hu D., Wang L.: Preparation and physical properties of tara gum film reinforced with cellulose nanocrystals. International Journal of Biological Macromolecules, 86, 606-612 (2016).

https://doi.org/10.1016/j.ijbiomac.2016.01.104

[27] Park H. J., Weller C. L., Vergano P. J., Testin R. F.: Permeability and mechanical properties of cellulose-based edible films. Journal of Food Science, 58, 1361-1364 (1993).

https://doi.org/10.1111/j.1365-2621.1993.tb06183.x

[28] Anwar Z., Gulfraz M., Irshad M.: Agro-industrial lignocellulosic biomass a key to unlock the future bio-energy: A brief review. Journal of Radiation Research and Applied Sciences, 7, 163-173 (2014). https://doi.org/10.1016/j.jrras.2014.02.003

[29] Ashori A., Nourbakhsh A.: Performance properties of microcrystalline cellulose as a reinforcing agent in wood plastic composites. Composites Part B: Engineering, 41, 578-581 (2010). https://doi.org/10.1016/j.compositesb.2010.05.004

[30] Tye Y. Y., Lee K. T., Wan Abdullah W. N., Leh C. P.: The world availability of non-wood lignocellulosic biomass for the production of cellulosic ethanol and potential pretreatments for the enhancement of enzymatic saccharification. Renewable and Sustainable Energy Reviews, 60, 155-172 (2016).

https://doi.org/10.1016/j.rser.2016.01.072

[31] Fink H-P., Weigel P., Purz H. J., Ganster J.: Structure formation of regenerated cellulose materials from NMMOsolutions. Progress in Polymer Science, 26, 1473-1524 (2001). https://doi.org/10.1016/S0079-6700(01)00025-9

[32] Brinchi L., Cotana F., Fortunati E., Kenny J. M.: Production of nanocrystalline cellulose from lignocellulosic biomass: Technology and applications. Carbohydrate Polymers, 94, 154-169 (2013). https://doi.org/10.1016/j.carbpol.2013.01.033

[33] Shokri J., Adibkia K.: Application of cellulose and cellulose derivatives in pharmaceutical industries. in ' $\mathrm{Cel}$ lulose - Medical, pharmaceutical and electronic applications' (eds.: van de Ven T., Godbout L.) InTech, Rijeka (2013).

https://doi.org/10.5772/55178

[34] Ankerfors M.: Microfibrillated cellulose: Energy-efficient preparation techniques and key properties. Licentiate Thesis, KTH Royal Institute of Technology, Stockholm (2012).

[35] Hubbe M. A., Rojas O. J., Lucia L. A., Sain M.: Cellulosic nanocomposites: A review. Biorecources, 3, 929 980 (2008).

[36] Siró I., Plackett D.: Microfibrillated cellulose and new nanocomposite materials: A review. Cellulose, 17, 459494 (2010).

https://doi.org/10.1007/s10570-010-9405-y
[37] Wu T., Farnood R., O’Kelly K., Chen B.: Mechanical behavior of transparent nanofibrillar cellulose-chitosan nanocomposite films in dry and wet conditions. Journal of the Mechanical Behavior of Biomedical Materials, 32, 279-286 (2014).

https://doi.org/10.1016/j.jmbbm.2014.01.014

[38] Abdul Khalil H. P. S., Saurabh C. K., Adnan A. S., Fazita M. R. N., Syakir M. I., Davoudpour Y., Rafatullah M., Abdullah C. K., Haafiz M. K. M., Dungani R.: A review on chitosan-cellulose blends and nanocellulose reinforced chitosan biocomposites: Properties and their applications. Carbohydrate Polymers, 150, 216-226 (2016). https://doi.org/10.1016/j.carbpol.2016.05.028

[39] Eichhorn S. J., Young R. J.: The Young's modulus of a microcrystalline cellulose. Cellulose, 8, 197-207 (2001). https://doi.org/10.1023/A:1013181804540

[40] Moon R. J., Martini A., Nairn J., Simonsen J., Youngblood J.: Cellulose nanomaterials review: Structure, properties and nanocomposites. Chemical Society Reviews, 40, 3941-3994 (2011). https://doi.org/10.1039/C0CS00108B

[41] Siqueira G., Bras J., Dufresne A.: Cellulosic bionanocomposites: A review of preparation, properties and applications. Polymers, 2, 728-765 (2010).

https://doi.org/10.3390/polym2040728

[42] Ioelovich M., Leykin A.: Study of sorption properties of cellulose and its derivatives. Bioresources, 6, 178195 (2011).

[43] Criado P., Fraschini C., Salmieri S., Becher D., Safrany A., Lacroix M.: Free radical grafting of gallic acid (GA) on cellulose nanocrystals (CNCS) and evaluation of antioxidant reinforced gellan gum films. Radiation Physics and Chemistry, 118, 61-69 (2016).

https://doi.org/10.1016/j.radphyschem.2015.05.030

[44] Edgar K. J., Buchanan C. M., Debenham J. S., Rundquist P. A., Seiler B. D., Shelton M. C., Tindall D.: Advances in cellulose ester performance and application. Progress in Polymer Science, 26, 1605-1688 (2001). https://doi.org/10.1016/S0079-6700(01)00027-2

[45] Ohkawa K., Hachisu M., Devarayan K., Araki J.: Design and synthesis of peptide-cellulose conjugate molecules; Aspects from energy/steric profiles. Fibers and Polymers, 14, 1970-1974 (2013). https://doi.org/10.1007/s12221-013-1970-x

[46] Miller K. S., Krochta J. M.: Oxygen and aroma barrier properties of edible films: A review. Trends in Food Science and Technology, 8, 228-237 (1997).

https://doi.org/10.1016/S0924-2244(97)01051-0

[47] Feng L., Chen Z-L.: Research progress on dissolution and functional modification of cellulose in ionic liquids. Journal of Molecular Liquids, 142, 1-5 (2008). https://doi.org/10.1016/j.molliq.2008.06.007

[48] Pinkert A., Marsh K. N., Pang S., Staiger M. P.: Ionic liquids and their interaction with cellulose. Chemical Reviews, 109, 6712-6728 (2009). https://doi.org/10.1021/cr9001947 
[49] Isik M., Sardon H., Mecerreyes D.: Ionic liquids and cellulose: Dissolution, chemical modification and preparation of new cellulosic materials. International Journal of Molecular Sciences, 15, 11922-11940 (2014).

https://doi.org/10.3390/ijms150711922

[50] de Oliveira Barud H. G., da Silva R. R., da Silva Barud H., Tercjak A., Gutierrez J., Lustri W. R., de Oliveira O. B., Ribeiro S. J.: A multipurpose natural and renewable polymer in medical applications: Bacterial cellulose. Carbohydrate Polymers, 153, 406-420 (2016). https://doi.org/10.1016/j.carbpol.2016.07.059

[51] Indrarti L., Indriyati, Syampurwadi A., Pujiastuti S.: Physical and mechanical properties of modified bacterial cellulose composite films. International Symposium on Frontier of Applied Physics, 1711, 050007/1-050007/5 (2016). https://doi.org/10.1063/1.4941633

[52] Rojas-Graü M. A., Avena-Bustillos R. J., Olsen C., Friedman M., Henika P. R., Martín-Belloso O., Pan Z., McHugh T. H.: Effects of plant essential oils and oil compounds on mechanical, barrier and antimicrobial properties of alginate-apple puree edible films. Journal of Food Engineering, 81, 634-641 (2007). https://doi.org/10.1016/j.jfoodeng.2007.01.007

[53] Maizura M., Fazilah A., Norziah M. H., Karim A. A.: Antibacterial activity and mechanical properties of partially hydrolyzed sago starch-alginate edible film containing lemongrass oil. Journal of Food Science, 72, C324-C330 (2007).

https://doi.org/10.1111/j.1750-3841.2007.00427.x

[54] Abdollahi M., Alboofetileh M., Rezaei M., Behrooz R.: Comparing physico-mechanical and thermal properties of alginate nanocomposite films reinforced with organic and/or inorganic nanofillers. Food Hydrocolloids, 32, 416-424 (2013).

https://doi.org/10.1016/j.foodhyd.2013.02.006

[55] Zhang Y., Ma Q., Critzer F., Davidson P. M., Zhong Q.: Physical and antibacterial properties of alginate films containing cinnamon bark oil and soybean oil. LWT Food Science and Technology, 64, 423-430 (2015). https://doi.org/10.1016/j.1wt.2015.05.008

[56] Shankar S., Wang L-F., Rhim J-W.: Preparations and characterization of alginate/silver composite films: Effect of types of silver particles. Carbohydrate Polymers, 146, 208-216 (2016).

https://doi.org/10.1016/j.carbpol.2016.03.026

[57] Kanmani P., Rhim J-W.: Development and characterization of carrageenan/grapefruit seed extract composite films for active packaging. International Journal of Biological Macromolecules, 68, 258-266 (2014). https://doi.org/10.1016/j.ijbiomac.2014.05.011

[58] Shojaee-Aliabadia S., Mohammadifar M. A., Hosseini H., Mohammadi A., Ghasemlou M., Hosseini S. M., Haghshenas M., Khaksar R.: Characterization of nanobiocomposite kappa-carrageenan film with Zataria multiflora essential oil and nanoclay. International Journal of Biological Macromolecules, 69, 282-289 (2014). https://doi.org/10.1016/j.ijbiomac.2014.05.015
[59] Rhim J-W., Wang L-F.: Preparation and characterization of carrageenan-based nanocomposite films reinforced with clay mineral and silver nanoparticles. Applied Clay Science, 97-98, 174-181 (2014). https://doi.org/10.1016/j.clay.2014.05.025

[60] Soni A., Kandeepan G., Mendiratta S. K., Shukla V., Kumar A.: Development and characterization of essential oils incorporated carrageenan based edible film for packaging of chicken patties. Nutrition and Food Science, 46, 82-95 (2016).

https://doi.org/10.1108/NFS-05-2015-0065

[61] Shankar S., Reddy J. P., Rhim J-W., Kim H-Y.: Preparation, characterization, and antimicrobial activity of chitin nanofibrils reinforced carrageenan nanocomposite films. Carbohydrate Polymers, 117, 468-475 (2015). https://doi.org/10.1016/j.carbpol.2014.10.010

[62] Fouda M. M. G., El-Aassar M. R., El Fawal G. F., Hafez E. E., Masry S. H. D., Abdel-Megeed A.: K-Carrageenan/poly vinyl pyrollidone/polyethylene glycol/silver nanoparticles film for biomedical application. International Journal of Biological Macromolecules, 74, 179-184 (2015). https://doi.org/10.1016/j.ijbiomac.2014.11.040

[63] Ghosh S., Kaushik R., Nagalakshmi K., Hoti S. L., Menezes G. A., Harish B. N., Vasan H. N.: Antimicrobial activity of highly stable silver nanoparticles embedded in agar-agar matrix as a thin film. Carbohydrate Research, 345, 2220-2227 (2010). https://doi.org/10.1016/j.carres.2010.08.001

[64] Rhim J. W., Wang L. F., Hong S. I.: Preparation and characterization of agar/silver nanoparticles composite films with antimicrobial activity. Food Hydrocolloids, 33, 327-335 (2013).

https://doi.org/10.1016/j.foodhyd.2013.04.002

[65] Rhim J-W.: Effect of clay contents on mechanical and water vapor barrier properties of agar-based nanocomposite films. Carbohydrate Polymers, 86, 691-699 (2011). https://doi.org/10.1016/j.carbpol.2011.05.010

[66] Orsuwan A., Shankar S., Wang L-F., Sothornvit R., Rhim J-W.: Preparation of antimicrobial agar/banana powder blend films reinforced with silver nanoparticles. Food Hydrocolloids, 60, 476-485 (2016). https://doi.org/10.1016/j.foodhyd.2016.04.017

[67] Vejdan A., Ojagh S. M., Adeli A., Abdollahi M.: Effect of $\mathrm{TiO}_{2}$ nanoparticles on the physico-mechanical and ultraviolet light barrier properties of fish gelatin/agar bilayer film. LWT -Food Science and Technology, 71, 88-95 (2016).

https://doi.org/10.1016/j.lwt.2016.03.011

[68] Abdou E. S., Sorour M. A.: Preparation and characterization of starch/carrageenan edible films. International Food Research Journal, 21, 189-193 (2014).

[69] Rhim J-W.: Physical-mechanical properties of agar/אcarrageenan blend film and derived clay nanocomposite film. Journal of Food Science, 77, N66-N73 (2012). https://doi.org/10.1111/j.1750-3841.2012.02988.x 
[70] Jumaidin R., Sapuan S. M., Jawaid M., Ishak M. R., Sahari J.: Characteristics of thermoplastic sugar palm starch/ agar blend: Thermal, tensile, and physical properties. International Journal of Biological Macromolecules, 89, 575-581 (2016).

https://doi.org/10.1016/j.ijbiomac.2016.05.028

[71] Wu Y., Geng F., Chang P. R., Yu J., Ma X.: Effect of agar on the microstructure and performance of potato starch film. Carbohydrate Polymers, 76, 299-304 (2009). https://doi.org/10.1016/j.carbpol.2008.10.031

[72] Ayranci E., Tunc S.: The effect of fatty acid content on water vapour and carbon dioxide transmissions of cellulose-based edible films. Food Chemistry, 72, 231-236 (2001). https://doi.org/10.1016/S0308-8146(00)00227-2

[73] do Socorro Rocha Bastos M., da Silva Laurentino L., Canuto K. M., Mendes L. G., Martins C. M., Silva S. M. F., Furtado R. F., Kim S., Biswas A., Cheng H. N.: Physical and mechanical testing of essential oil-embedded cellulose ester films. Polymer Testing, 49, 156-161 (2016). https://doi.org/10.1016/j.polymertesting.2015.11.006

[74] Kester J. J., Fennema O.: An edible film of lipids and cellulose ethers: Barrier properties to moisture vapor transmission and structural evaluation. Journal of Food Science, 54, 1383-1389 (1989).

https://doi.org/10.1111/j.1365-2621.1989.tb05118.x

[75] Klangmuang P., Sothornvit R.: Combination of beeswax and nanoclay on barriers, sorption isotherm and mechanical properties of hydroxypropyl methylcellulosebased composite films. LWT - Food Science and Technology, 65, 222-227 (2016).

https://doi.org/10.1016/j.lwt.2015.08.003

[76] Santos D. C., Ribeiro Santos R., Ventura L. A. F., Melo N. R., de Sá Costa B., Rojas E. E. G., Salgado N. L.: Antimicrobial activity studies and characterization of cellulose acetate films containing essential oils. Italian Journal of Food Science, 28, 248-257 (2016).

https://doi.org/10.14674/1120-1770\%2Fijfs.v28

[77] Coma V., Sebti I., Pardon P., Pichavant F. H., Deschamps A.: Film properties from crosslinking of cellulosic derivatives with a polyfunctional carboxylic acid. Carbohydrate Polymers, 51, 265-271 (2003).

https://doi.org/10.1016/S0144-8617(02)00191-1

[78] Donhowe G. I., Fennema O.: The effects of plasticizers on crystallinity, permeability, and mechanical properties of methylcellulose films. Journal of Food Processing and Preservation, 17, 247-257 (1993).

https://doi.org/10.1111/j.1745-4549.1993.tb00729.x

[79] Othman S. H.: Bio-nanocomposite materials for food packaging applications: Types of biopolymer and nanosized filler. Agriculture and Agricultural Science Procedia, 2, 296-303 (2014).

https://doi.org/10.1016/j.aaspro.2014.11.042

[80] Shankar S., Rhim J-W.: Preparation of nanocellulose from micro-crystalline cellulose: The effect on the performance and properties of agar-based composite films. Carbohydrate Polymers, 135, 18-26 (2016).

https://doi.org/10.1016/j.carbpol.2015.08.082
[81] Hu D., Wang H., Wang L.: Physical properties and antibacterial activity of quaternized chitosan/carboxymethyl cellulose blend films. LWT - Food Science and Technology, 65, 398-405 (2016). https://doi.org/10.1016/j.lwt.2015.08.033

[82] Rico M., Rodríguez-Llamazares S., Barrala L., Bouza R., Montero B.: Processing and characterization of polyols plasticized-starch reinforced with microcrystalline cellulose. Carbohydrate Polymers, 149, 83-93 (2016). https://doi.org/10.1016/j.carbpol.2016.04.087

[83] de Mesquita J. P., Donnici C. L., Teixeira I. F., Pereira F. V.: Bio-based nanocomposites obtained through covalent linkage between chitosan and cellulose nanocrystals. Carbohydrate Polymers, 90, 210-217 (2012). https://doi.org/10.1016/j.carbpol.2012.05.025

[84] Miranda C. S., Ferreira M. S., Magalhães M. T., Santos W. J., Oliveira J. C., Silva J. B. A., José N. M.: Mechanical, thermal and barrier properties of starch-based films plasticized with glycerol and lignin and reinforced with cellulose nanocrystals. Materials Today: Proceedings, 2, 63-69 (2015). https://doi.org/10.1016/j.matpr.2015.04.009

[85] Oun A. A., Rhim J-W.: Isolation of cellulose nanocrystals from grain straws and their use for the preparation of carboxymethyl cellulose-based nanocomposite films. Carbohydrate Polymers, 150, 187-200 (2016). https://doi.org/10.1016/j.carbpol.2016.05.020

[86] Kaushik A., Singh M., Verma G.: Green nanocomposites based on thermoplastic starch and steam exploded cellulose nanofibrils from wheat straw. Carbohydrate Polymers, 82, 337-345 (2010).

https://doi.org/10.1016/j.carbpol.2010.04.063

[87] Fernandes S. C. M., Freire C. S. R., Silvestre A. J. D., Neto C. P., Gandini A., Berglund L. A., Salmén L.: Transparent chitosan films reinforced with a high content of nanofibrillated cellulose. Carbohydrate Polymers, 81, 394-401 (2010). https://doi.org/10.1016/j.carbpol.2010.02.037

[88] Oun A. A., Rhim J-W.: Preparation and characterization of sodium carboxymethyl cellulose/cotton linter cellulose nanofibril composite films. Carbohydrate Polymers, 127, 101-109 (2015).

https://doi.org/10.1016/j.carbpol.2015.03.073

[89] Ghanbarzadeh B., Almasi H., Entezami A. A.: Improving the barrier and mechanical properties of corn starchbased edible films: Effect of citric acid and carboxymethyl cellulose. Industrial Crops and Products, 33, 229235 (2011). https://doi.org/10.1016/j.indcrop.2010.10.016

[90] Su J-F., Huang Z., Yuan X-Y., Wang X-Y., Li M.: Structure and properties of carboxymethyl cellulose/soy protein isolate blend edible films crosslinked by Maillard reactions. Carbohydrate Polymers, 79, 145-153 (2010). https://doi.org/10.1016/j.carbpol.2009.07.035 
[91] Azeredo H. M. C., Miranda K. W. E., Rosa M. F., Nascimento D. M., de Moura M. R.: Edible films from alginate-acerola puree reinforced with cellulose whiskers. LWT - Food Science and Technology, 46, 294-297 (2012).

https://doi.org/10.1016/j.lwt.2011.09.016

[92] Liu K., Lin X., Chen L., Huang L., Cao S., Wang H.: Preparation of microfibrillated cellulose/chitosanbenzalkonium chloride biocomposite for enhancing antibacterium and strength of sodium alginate films. Journal of Agricultural and Food Chemistry, 61, 6562 6567 (2013).

https://doi.org/10.1021/jf4010065

[93] Yadav M., Rhee K. Y., Park S. J.: Synthesis and characterization of graphene oxide/carboxymethylcellulose/alginate composite blend films. Carbohydrate Polymers, 110, 18-25 (2014).

https://doi.org/10.1016/j.carbpol.2014.03.037

[94] Sirviö J. A., Kolehmainen A., Liimatainen H., Niinimäki J., Hormi O. E. O.: Biocomposite cellulose-alginate films: Promising packaging materials. Food Chemistry, 151, 343-351 (2014).

https://doi.org/10.1016/j.foodchem.2013.11.037

[95] Lin Q., Zheng Y., Ren L., Wu J., Wang H., An J., Fan W.: Preparation and characteristic of a sodium alginate/carboxymethylated bacterial cellulose composite with a crosslinking semi-interpenetrating network. Journal of Applied Polymer Sciences, 131, 39848/139848/9 (2014).

https://doi.org/10.1002/app.39848

[96] Shao W., Liu H., Liu X., Wang S., Wu J., Zhang R., Min H., Huang M.: Development of silver sulfadiazine loaded bacterial cellulose/sodium alginate composite films with enhanced antibacterial property. Carbohydrate Polymers, 132, 351-358 (2015).

https://doi.org/10.1016/j.carbpol.2015.06.057

[97] Sritweesinsub W., Charuchinda S.: Alginate/carboxymethyl cellulose hydrogel films in relation to crosslinking with glutaraldehyde and copper sulfate. in 'MATEC Web of Conferences. France' Vol 30, 1-4 (2015).

https://doi.org/10.1051/matecconf/20153002005

[98] Deepa B., Abraham E., Pothan L. A., Cordeiro N., Faria M., Thomas S.: Biodegradable nanocomposite films based on sodium alginate and cellulose nanofibrils. Materials, 9, 9010050/1-9010050/11 (2016). https://doi.org/10.3390/ma9010050

[99] Wang K., Nune K. C., Misra R. D. K.: The functional response of alginate-gelatin-nanocrystalline cellulose injectable hydrogels toward delivery of cells and bioactive molecules. Acta Biomaterialia, 36, 143-151 (2016). https://doi.org/10.1016/j.actbio.2016.03.016

[100] Savadekar N. R., Karande V. S., Vigneshwaran N., Bharimalla A. K., Mhaske S. T.: Preparation of nano cellulose fibers and its application in kappa-carrageenan based film. International Journal of Biological Macromolecules, 51, 1008-1013 (2012). https://doi.org/10.1016/j.ijbiomac.2012.08.014
[101] Alves V. D., Costa N., Coelhoso I. M.: Barrier properties of biodegradable composite films based on kappacarrageenan/pectin blends and mica flakes. Carbohydrate Polymers, 79, 269-276 (2010). https://doi.org/10.1016/j.carbpol.2009.08.002

[102] Domínguez-Courtney M. F., López-Malo A., Palou E., Jiménez-Munguía M. T.: Optimization of mechanical properties of carboxymethyl cellulose, carrageenan and/or xanthan gum gels as alternatives of gelatin softgels capsules. Journal of Multidisciplinary Engineering Science and Technology, 2, 3132-3140 (2015).

[103] Rudhziah S., Rani M. S. A., Ahmad A., Mohamed N. S., Kaddami H.: Potential of blend of kappa-carrageenan and cellulose derivatives for green polymer electrolyte application. Industrial Crops and Products, 72, 133-141 (2015). https://doi.org/10.1016/j.indcrop.2014.12.051

[104] Zarina S., Ahmad I.: Biodegradable composite films based on $\kappa$-carrageenan reinforced by cellulose nanocrystal from kenaf fibres. Bioresources, 10, 256-271 (2015).

[105] Liu K., Lin X., Chen L., Huang L., Cao S.: Dual-functional chitosan-methylisothiazolinone/microfibrillated cellulose biocomposites for enhancing antibacterial and mechanical properties of agar films. Cellulose, 21, 519-528 (2014). https://doi.org/10.1007/s10570-013-0145-7

[106] Rhim J-W., Reddy J. P., Luo X.: Isolation of cellulose nanocrystals from onion skin and their utilization for the preparation of agar-based bio-nanocomposites films. Cellulose, 22, 407-420 (2015). https://doi.org/10.1007/s10570-014-0517-7

[107] Atef M., Rezaei M., Behrooz R.: Characterization of physical, mechanical, and antibacterial properties of agar-cellulose bionanocomposite films incorporated with savory essential oil. Food Hydrocolloids, 45, 150157 (2015). https://doi.org/10.1016/j.foodhyd.2014.09.037

[108] Jiménez A., Fabra M. J., Talens P., Chiralt A.: Edible and biodegradable starch films: A review. Food and Bioprocess Technology, 5, 2058-2076 (2012). https://doi.org/10.1007/s11947-012-0835-4

[109] Siah W. M., Aminah A., Ishak A.: Edible films from seaweed (Kappaphycus alvarezii). International Food Research Journal, 22, 2230-2236 (2015).

[110] Imre B., Pukánszky B.: Compatibilization in bio-based and biodegradable polymer blends. European Polymer Journal, 49, 1215-1233 (2013). https://doi.org/10.1016/j.eurpolymj.2013.01.019

[111] Rogovina S., Aleksanyan K., Prut E., Gorenberg A.: Biodegradable blends of cellulose with synthetic polymers and some other polysaccharides. European Polymer Journal, 49, 194-202 (2013). https://doi.org/10.1016/j.eurpolymj.2012.10.002

[112] Sannino A., Demitri C., Madaghiele M.: Biodegradable cellulose-based hydrogels: Design and applications. Materials, 2, 353-373 (2009). https://doi.org/10.3390/ma2020353 
[113] Leja K., Lewandowicz G.: Polymer biodegradation and biodegradable polymers - A review. Polish Journal of Environmental Studies, 19, 255-266 (2010).

[114] Premraj R., Doble M.: Biodegradation of polymers. Indian Journal of Biotechnology, 4, 186-193 (2005).

[115] Jawaid M., Abdul Khalil H. P. S.: Cellulosic/synthetic fibre reinforced polymer hybrid composites: A review. Carbohydrate Polymers, 86, 1-18 (2011). https://doi.org/10.1016/j.carbpol.2011.04.043

[116] Tye Y. Y., Lee K. T., Wan Abdullah W. N., Leh C. P.: Potential of Ceiba pentandra (L.) Gaertn. (kapok fiber) as a resource for second generation bioethanol: Effect of various simple pretreatment methods on sugar production. Bioresource Technology, 116, 536-539 (2012). https://doi.org/10.1016/j.biortech.2012.04.025

[117] Cowling E. B.: A review of literature on the enzymatic degradation of cellulose and wood. Forest Products Laboratory, Madison (1958).

[118] Zugenmaier P.: Crystalline cellulose and cellulose derivatives. Springer, New York (2008).
[119] Sharma S., Horn S. J.: Enzymatic saccharification of brown seaweed for production of fermentable sugars. Bioresource Technology, 213, 155-161 (2016). https://doi.org/10.1016/j.biortech.2016.02.090

[120] Chbani A., Mawlawi H., Zaouk L.: Evaluation of brown seaweed (Padina pavonica) as biostimulant of plant growth and development. African Journal of Agricultural Research, 8, 1155-1165 (2013). https://doi.org/10.5897/AJAR12.1346

[121] McCormick K., Kautto N.: The bioeconomy in Europe: An overview. Sustainability, 5, 2589-2608 (2013). https://doi.org/10.3390/su5062589

[122] Herlekar I.: Biodegradable ropes from seaweed extracts. Current Science, 108, 2140 (2015). https://doi.org/10.18520/cs/v108/i12/2140-2140

[123] Flieger M., Kantorová M., Prell A., Rezanka T., Votruba J.: Biodegradable plastics from renewable sources. Folia Microbiologica, 48, 27-44 (2003).

[124] You C., Chen H., Myung S., Sathitsuksanoh N., Ma H., Zhang X-Z., Li J., Zhang Y-H. P.: Enzymatic transformation of nonfood biomass to starch. Proceedings of the National Academy of Sciences, 110, 7182-7187 (2013).

https://doi.org/10.1073/pnas.1302420110 